\title{
Contemporaneous opening of the Alpine Tethys in the Eastern and Western Alps: constraints from a Late Jurassic gabbro intrusion age in the Glockner Nappe, Tauern Window, Austria
}

\author{
Philipp Gleißner ${ }^{1,2}$ (D) Gerhard Franz ${ }^{2} \cdot$ Dirk Frei $^{3,4}$
}

Received: 5 February 2021 / Accepted: 11 June 2021 / Published online: 1 July 2021

(c) The Author(s) 2021

\begin{abstract}
Metabasic rocks of the ophiolitic sequences of the Glockner Nappe and Eclogite Zone in the south-central Tauern Window, Austria, reveal important insights into rifting and spreading of the Alpine Tethys. U-Pb dating of magmatic zircons yields a concordant $157 \pm 2$ Ma crystallization age for the precursor of a coarse-grained metagabbro from the Glockner Nappe. The Late Jurassic intrusion age is coeval with mafic plutonic activity in the Western and Central Alps. Although Penninic ophiolitic sequences in tectonic windows of the Eastern Alps are usually disrupted, an ocean-continent transition setting can be reconstructed for the Glockner Nappe, similar to many ophiolites in the Liguria-Piemont domain in the Western and Central Alps. Together, these observations strongly suggest a formation in the Liguria-Piemont branch of the Alpine Tethys and are inconsistent with a formation in the Valais domain. This finding has important implications for paleogeographic reconstructions of the Penninic realm in the Eastern Alps. Whereas the Glockner Nappe metagabbro and metabasalts clearly reveal their depleted mantle origin, the metabasic rocks of the Eclogite Zone record a more complex formation history involving depleted mantle melting and crustal assimilation in a continental margin setting.
\end{abstract}

Keywords Alpine Tethys $\cdot$ Tauern Window $\cdot$ Metagabbro $\cdot \mathrm{U}-\mathrm{Pb}$ zircon

\section{Introduction}

The break-up of Pangaea and Permo-Triassic rifting led to lithospheric thinning and subsidence at the southern European margin. The stepwise protrusion of the Atlantic Ocean to the north caused the development of distinct oceanic basins within a transform system between the opening Atlantic Ocean in the West and the Tethys area in the East (e.g., Kurz 2006; Stampfli et al. 1998). Together these

Philipp Gleißner

gleissner@zedat.fu-berlin.de

1 Institut Für Geologische Wissenschaften, Freie Universität Berlin, Malteserstr. 74-100, 12249 Berlin, Germany

2 Institut Für Angewandte Geowissenschaften, Technische Universität Berlin, Ernst-Reuter-Platz 1, 10587 Berlin, Germany

3 Department of Earth Sciences, Stellenbosch University, Private Bag X1, Matieland 7602, Republic of South Africa

4 Department of Earth Sciences, University of the Western Cape, Private Bag X17, Bellville 7535, Republic of South Africa
Jurassic to Cretaceous ocean basins are referred to as Alpine Tethys or Western Tethys (e.g., Kurz 2006; Schmid et al., 2004; Stampfli et al. 1998). The magmatic and sedimentary sequences of many Alpine units have been established and their tectonic preposition in the later Alpine orogeny has been set during this period. Late Cretaceous to Oligocene closure of the Alpine Tethys due to subduction of the oceanic basins (Penninic nappes) and parts of the European continental margin (Subpenninic nappes) resulted in variable metamorphic overprint of older units and merged the complex Alpine nappe system (e.g., Agard 2021; Balestro et al. 2019). In this framework, both the timing of sea-floor spreading and the mantle sources for mafic-ultramafic igneous rocks are important data for reconstruction of the tectonic processes before the onset of the Alpine orogeny (e.g., Handy et al. 2010; Kurz 2006; Schmid et al. 2004).

In this contribution, we present new geochronological and geochemical data for metabasic rocks from the Glockner Nappe and the Eclogite Zone of the south-central Tauern Window. Based on field relations, textures and compositions we discuss their magmatic formation, metamorphic overprint and constraints on compositions of their respective 
mantle sources. Zircons with magmatic growth zonation from one metagabbro sample yield a concordant $\mathrm{U}-\mathrm{Pb}$ age. This age, together with constraints on the protoliths of mafic and ultramafic lithologies, allows for comparison to similar data from the Western and Central Alps and shed new light on the timing of rifting and sea-floor spreading in the Alpine Tethys preserved in the Penninic units in the Tauern Window.

\section{Geological framework}

In the Western and Central Alps, ophiolitic sequences allow the reconstruction of rifting and sea-floor spreading processes in the Alpine Tethys. In the present Alpine, orogen remnants of Liguria-Piemont (Southpenninic) and Valais (Northpenninic) sub-basins of the Alpine Tethys are separated by the Briançonnais (Middlepenninic), a fragment of continental lithosphere that rifted from the European continental margin (Subpenninic) and was involved in subduction and Alpine nappe stacking (Froitzheim and Manatschal 1996; Stampfli et al. 1998). Following recent reviews on the structural architecture and tectonic evolution of the western Alpine ophiolites (e.g., Agard 2021; Balestro et al. 2019) and according to their paleogeographic position in the Alpine Tethys from West to East, in this study, we refer to the Liguria-Piemont ocean (instead of Piemont-Liguria ocean, which is also used). Structural and compositional analysis of ophiolites assigned to the Liguria-Piemont oceanic lithosphere show characteristics of magma-poor rifted margins similar to modern-day analogues (e.g., Manatschal and Müntener 2009; Rampone et al. 1998; Schaltegger et al. 2002). Based on recent plate-tectonic reconstructions the opening of the Liguria-Piemont ocean basin began before $\sim 200 \mathrm{Ma}$ and sea-floor spreading started at $\sim 170 \mathrm{Ma}$ and lasted until $131 \mathrm{Ma}$ (Balestro et al. 2019; Costa and Caby 2001; Handy et al. 2010; Principi, 2004). The oblique opening of the Valais ocean basin was linked to the opening of the Bay of Biscay and is inferred to begin with rifting from the Jurassic-Cretaceous boundary followed by sea-floor spreading from 130 to $93 \mathrm{Ma}$ (Handy et al. 2010; Stampfli et al. 1998). However, the record of magmatic activity in the Valais paleogeographic domain is rather limited and the affiliation of individual units and the available age data are still discussed (see discussion in Handy et al. 2010; Kurz 2006; Manatschal and Müntener 2009; Schmid et al. 2004).

The Eastern Alps are dominated by Austroalpine units and their record of Eoalpine (Cretaceous) metamorphism. However, a few tectonic windows expose deeper nappes of the Alpine orogen (Fig. 1a). In the Tauern Window, continental (meta)igneous and (meta)sedimentary units (Venediger Nappe complex) underly the Glockner Nappe and Matrei Zone, units consisting dominantly of metaigneous and metasedimentary rocks with ocean floor affinities (Fig. 1b).
Although the intense deformation during the Alpine tectonometamorphic history obliterated most original stratigraphic relationships between different lithologies, many authors have concluded that metabasic rocks and calcareous metasediment successions, especially those associated with metagabbros and serpentinites, are remnants of a former ocean floor (e.g., Bickle and Pearce 1975; Höck and Koller 1989; Miller 1977). Furthermore, because of their tectono-stratigraphic position within the Alpine nappe stack, it was suggested that the observed incomplete ophiolite sequences of the Tauern Window might have a contemporaneous origin with ophiolite sequences of the Western and Central Alps (Höck and Scharbert 1989; Melcher et al. 2002). However, their affiliation with either the Liguria-Piemont or Valais ocean basin is still debated (e.g., Kurz 2006; Schmid et al. 2004, 2013). Linking the Penninic units of the Tauern Window to one or the other oceanic basin of the Alpine Tethys is complicated by the apparent absence of the Briançonnais nappe and the lack of robust age constraints (see discussion in Kurz 2006; Schmid et al. 2013). In the Glockner Nappe, metamorphism and deformation largely obliterated the microfossil record in metasediments (Bertle 2004) and hampered the radiometric dating of magmatic events (Meisel et al. 1997).

Another, spatially more restricted unit with proposed oceanic affinities is the Eclogite Zone in the south-central Tauern Window. It forms a distinct nappe and is tectonically sandwiched between the Subpenninic Venediger Nappe complex and the Rote-Wand-Modereck Nappe, which consists mainly of continental basement with Mesozoic cover (Kurz et al. 1998). It comprises the youngest Alpine eclogites (Glodny et al. 2005; Nagel et al. 2013) intercalated with siliciclastic (Spear and Franz 1986) and carbonaceous metasediments (Franz and Spear 1983; Miller et al. 2007; Raith et al. 1980). Relict textures and chemical composition of eclogites and retrogressed eclogites are interpreted as indicative of submarine emplacement of basaltic and gabbroic rocks (Höck and Miller 1987; Miller 1977). The metabasite-metasediment association is believed to represent an initial rift stage before sea-floor spreading and simultaneous sediment deposition along the slope of the south European continental margin (e.g., Kurz et al. 1998; Schmid et al. 2013). Available isotopic data for metabasic rocks reveal generally not only depleted mantle sources, but also assimilation of pre-Mesozoic continental basement (Nagel et al. 2013; von Quadt et al. 1997). However, age and tectonic setting of eclogite precursors remains enigmatic.

\section{Sample localities of metabasic rocks of the Glockner Nappe and the Eclogite Zone}

The main focus of this contribution are metagabbroic rocks of oceanic affinity within the Penninic units (Fig. 1c), which 

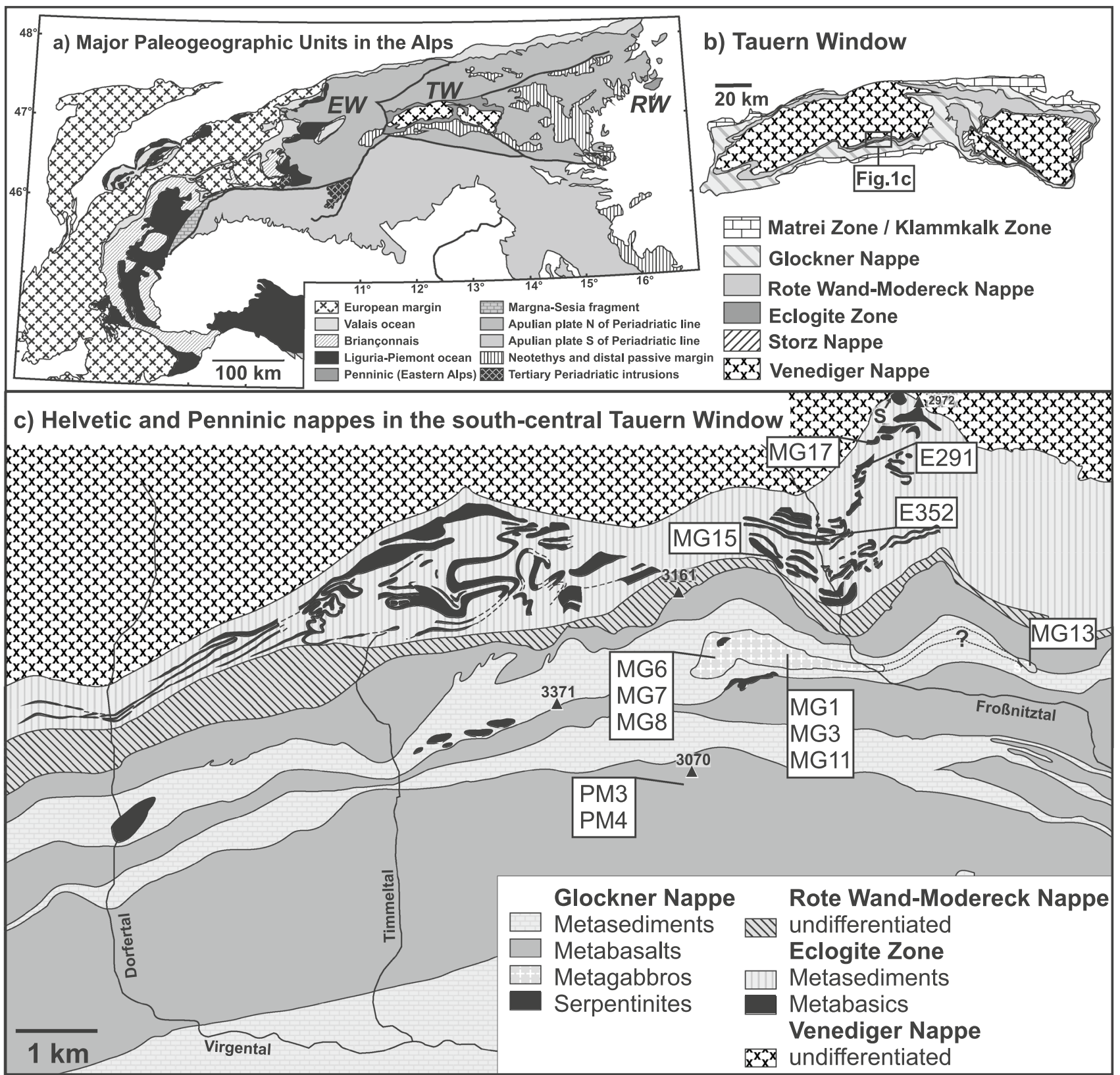

Fig. 1 Geological sketch maps. a Tectonic provenance map of the Alps, simplified after Schmid et al. (2004). Tectonic windows in the Eastern Alps: Engadine Window (EW), Tauern Window (TW) and Rechnitz Window group (RW). b Tectonic units within the Tauern

occur spatially associated with massive layers of metabasalts. The largest metagabbro occurrence in the Froßnitztal is a $\sim 0.9 \mathrm{~km}^{2}$ body (Fig. 2a) within and close to the base of the Glockner Nappe (Miller 1977). The rocks are described as prasinites with textures ranging from coarsegrained metagabbroic (Fig. 2b) to foliated with subparallel layering of mafic phases in more strongly deformed samples (Miller 1977). The body is elongated parallel to the dominant regional layering and separated from the surrounding
Window, modified after Kurz et al. (1998). c Glockner Nappe and Eclogite Zone in the south-central Tauern Window (after Raith et al. 1980 , and own mapping)

metasediments by strongly deformed chlorite schists and rodingites. A smaller outcrop, $\sim 1 \mathrm{~km}$ to the East is most likely the extension of the main body, but the area in between is covered by vegetation and talus material. Towards the West isolated smaller bodies of lherzolitic to harzburgitic serpentinites occur above the metagabbro and within the same horizon (Meisel et al. 1997; Miller 1977). Metagabbro and serpentinites are part of a layered succession of metabasalts and calcareous metasediments (Bündnerschiefer) in 

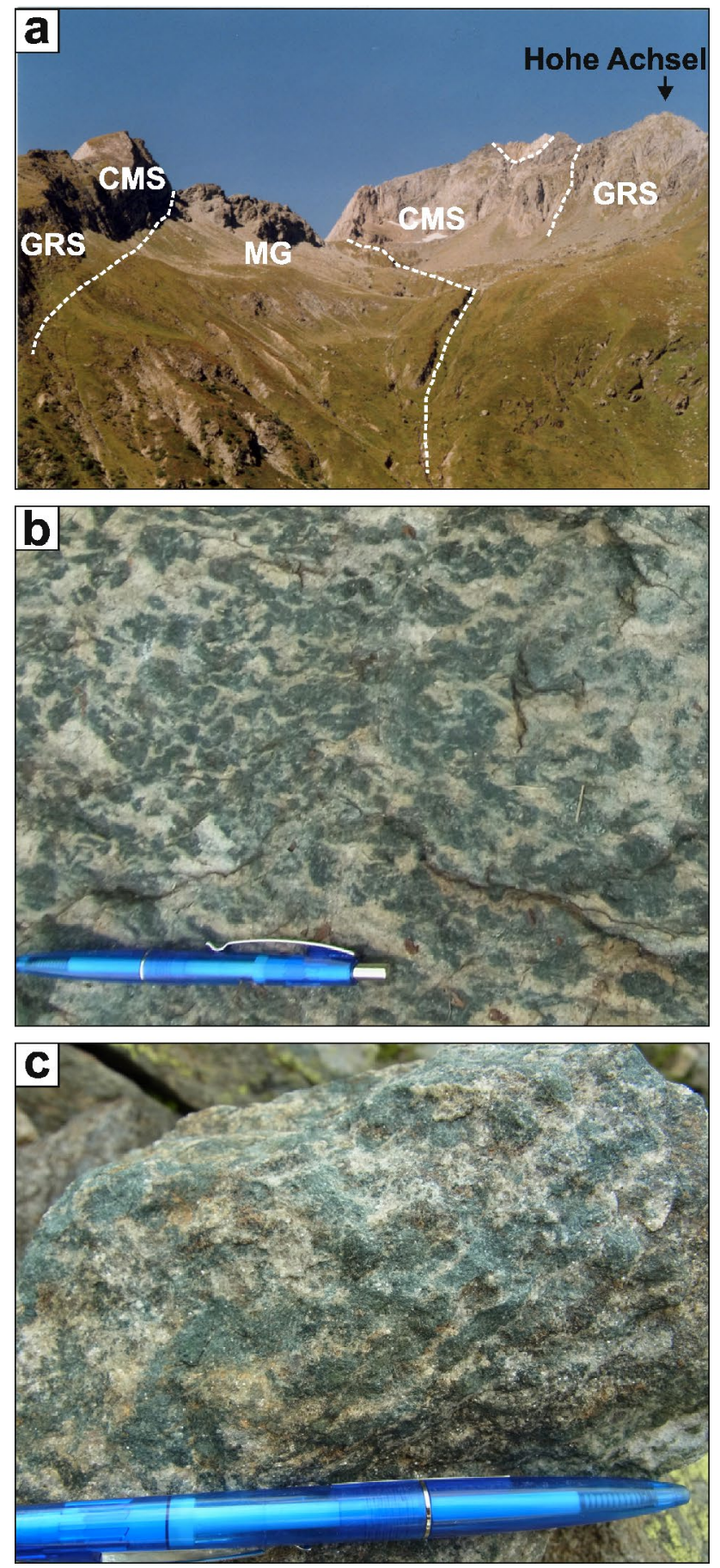

Fig. 2 Metagabbroic rocks in south-central Tauern Window. a Outcrop of the main metagabbro body in the Froßnitztal (view towards the West, $M G$ metagabbro, GRS greenschist, $C M S$ carbonaceous mica schist). b Coarse-grained prasinite (metagabbro) of the Glockner Nappe. c Coarse-grained eclogite of the Eclogite Zone

the Glockner Nappe which extends laterally for several $10 \mathrm{~s}$ of km (Unit I of Höck and Miller 1987). In the study area, several 10-100 s of meters thick greenschist layers occur above the metagabbro, but also below it, close to the contact with the underlying Rote-Wand-Modereck Nappe. Syntectonic crystallization of the greenschist facies assemblage and pseudomorph replacement of blueschist facies lawsonite in the greenschists of the Glockner Nappe has been dated at $29.8 \pm 0.5 \mathrm{Ma}$ (Gleissner et al. 2007). We sampled different zones of the main metagabbro body (Fig. 1c, samples MG1-MG11), the smaller metagabbro outcrop (sample MG13) and representative samples of the most massive greenschist layer (samples PM3 and PM4). Zircon is rare in the metagabbros, only one sample (MG13) yielded enough crystals for dating.

The Eclogite Zone comprises a similar succession of metabasic rocks and metasediments as observed in the Glockner Nappe, but with a higher fraction of siliciclastic metasediments (e.g., Kurz et al. 1998; Miller et al. 2007; Raith et al. 1980). In contrast to the thick greenschist layers of the Glockner Nappe, eclogite layers are thinner (meters to $10 \mathrm{~s}$ of meters) and display strong isoclinal folding (Fig. 1c). The majority of eclogites display massive or banded textures, interpreted as remnants of basaltic and volcaniclastic precursors (Miller 1977; Raith et al. 1980). Some exceptionally coarse-grained eclogites display large omphacite crystals (up to $2 \mathrm{~cm}$, Fig. 2c) in a finer grained matrix. Based on the observed texture, Miller (1977) interpreted those eclogites as metagabbros with the large omphacite crystals as pseudomorph after magmatic augite. Serpentinites have been described from the Eclogite Zone (Miller 1977), but are rare; a small outcrop at the base of the Eclogite Zone is indicated in Fig. 1c. We studied coarse-grained (samples MG15 and MG17) and fine-grained eclogites (samples E291 and E352) from massive eclogite layers along a profile approximately perpendicular to the main layering of the Eclogite Zone (Fig. 1c). In the Eclogite Zone internal isochrons of eclogites and related segregations reveal late-prograde dehydration and recrystallization under eclogite facies conditions at 31.5 $\pm 0.7 \mathrm{Ma}$ (Glodny et al. 2005; Nagel et al. 2013).

\section{Analytical methods}

Analysis of major and trace elements by wavelength-dispersive X-ray fluorescence spectrometry (XRF) was conducted at the Institute of Applied Geosciences, Technical University Berlin. Sample powders and $\mathrm{Li}_{2} \mathrm{~B}_{4} \mathrm{O}_{7}$-flux were fused to glass discs and analyzed with a PHILIPS PW 1404 or PHILIPS PW 2400 instrument. For control of consistency, international reference materials MGR-1 and JB-3 were analyzed as unknowns within the same analytical session. Losses on ignition were calculated from the mass difference for $2 \mathrm{~g}$ of powdered sample before and after heating at $1000{ }^{\circ} \mathrm{C}$ for $1 \mathrm{~h}$.

Electron microprobe analyses (EMPA) of all major phases in three metagabbro samples were conducted at the Institute 
of Applied Geosciences, Technical University Berlin and the Institute of Geological Sciences, Free University Berlin using a CAMECA Camebax Microbeam and a JEOL JXA 8200 Superprobe instrument, respectively. Natural and synthetic standards were used for instrument calibration. Mineral analyses were performed with an accelerating voltage of $15 \mathrm{kV}$, a beam current of $20 \mathrm{nA}$ and an electron beam of $1 \mu \mathrm{m}$ in diameter. The measured data were corrected with the ZAF method for absorption, background, atomic number and fluorescence.

Bulk rock trace element composition was analyzed at the Institute of Geological Sciences, Free University Berlin by inductively coupled plasma mass spectrometry (ICP-MS) following the analytical protocol described in Schneider et al. (2019). Approximately, $100 \mathrm{mg}$ of sample, powdered in an agate mill, were digested in concentrated $\mathrm{HF}-\mathrm{HNO}_{3}$ using Parr pressure vessels. After $\mathrm{HClO}_{4}$ addition and drying, the samples were repeatedly fluxed with concentrated $\mathrm{HNO}_{3}$ and then dissolved in $2 \% \mathrm{HNO}_{3}$ (+ trace $\mathrm{HF}$ ) for analysis. An internal standard solution of $1 \mathrm{ng} / \mathrm{g}$ Ge-In-Re was added to the final dilution to correct measured intensities of the low, middle and high masses for signal drift. Signals were detected using a Thermo-Electron Element XR instrument and calibrated against a calibration curve of several dilutions of BHVO-2 or BIR-1 reference material. To adopt the sample solutions to the calibration range we analyzed different dilutions for metagabbro samples (three different solutions with dilution factors between 1000 and 20,000) and metabasaltic samples (two different solutions with dilution factors between 17,000 and 100,000). Total analytical blanks, determined following this method, are generally $<0.01 \mathrm{ng}$ for rare-earth elements (REE) and $<0.1 \mathrm{ng}$ for other high field strength elements (HFSE) and large ion lithophile elements (LILE). Thus, blank contributions to the measured samples are generally insignificant except for $\mathrm{Cs}$, Ta, Th, and $\mathrm{U}$ in some metagabbro samples. According to blank levels, calibration range and associated uncertainties the procedural detection limit of our method is estimated as $0.0003 \mu \mathrm{g} / \mathrm{g}$ for REE and $0.003 \mu \mathrm{g} / \mathrm{g}$ for other HFSE and LILE. Accuracy and precision of our measurements were crosschecked with reference materials analyzed as unknowns in the same analytical session (BHVO-2, BIR-1, AVG-2, BCR-2). Based on reproducibility of reference materials and uncertainty of our calibration, uncertainties of concentration determinations are estimated as $<5 \%$ for REE and $<10 \%$ for other HFSE and LILE.

Zircons for age determination at the Department of Earth Sciences, Stellenbosch University were separated using standard techniques such as crushing, sieving, Wilfley separation table, Frantz magnetic separation and heavy liquid separation, followed by handpicking under a binocular microscope. Preparation and analytical methods are described in detail in Frei and Gerdes (2009). After mounting in epoxy resin, zircons were polished and studied by cathodoluminescence imaging using a LEO 1430 $\mathrm{VP}$ instrument. Zircons were analyzed for $\mathrm{U}$, Th and $\mathrm{Pb}$ by laser ablation inductively coupled plasma mass spectrometry (LA-ICP-MS) employing a Thermo Finnigan Element2 instrument coupled to a New Wave UP213 ultraviolet laser system. Data were acquired in peak jumping mode with a spot size of $30 \mu \mathrm{m}$. A common $\mathrm{Pb}$ correction, according to model Pb composition (Stacey and Kramers 1975), was applied to the interference and background corrected ${ }^{204} \mathrm{~Pb}$ signal when necessary. Uncertainties have been propagated by quadratic addition of within-run precision of each analysis (2 SD) and external reproducibility (2 SD) of zircon standard GJ-1 during the analytical session. For quality control, the reference M127 zircon material was analyzed and the results were in excellent agreement with the published isotope dilution TIMS ages (Nasdala, 2008). Concordia diagram and $\mathrm{U}-\mathrm{Pb}$ ages were calculated using Isoplot 3.75 software (Ludwig 2012).

\section{Results}

\section{Petrography and mineral chemistry}

Samples of the Glockner Nappe metagabbro are typically coarse-grained and display relict subophitic textures (Fig. 3a). Angular centimeter-sized grains and aggregates of dark green actinolite with numerous tiny grains of titanite are most likely pseudomorphs after magmatic Ti-augite. White to yellowish albite and zoisite fill the space between actinolite and most likely replaced subhedral lath-shaped igneous plagioclase. In samples with slight foliation the subophitic texture is less well preserved and albite and clinozoisite wrap around smaller and round actinolite aggregates (Fig. 3b). Phengite, titanite, chlorite (at the expense of actinolite), pyrite, rutile, and quartz are minor or accessory phases. Although somewhat different in texture, EMPA of major phases reveal identical compositions in MG3, MG11 and MG13 (Table 1 and Appendix 1). The Si content of actinolite (7.95-7.30 Si per formula unit) decreases slightly from the core of larger grains towards the rim and smaller crystals, but true magnesiohornblende is scarce. Albite is almost pure (Ab 97-99), chlorite is Mg-rich (3.48-4.26 Mg per formula unit), and phengite has 3.29-3.43 Si per formula unit. Less abundant leucocratic metagabbro samples are composed of zoisite/epidote, albite, minor actinolite and accessory titanite, quartz, and some Cr-rich muscovite. The marginal chlorite schists are composed of chlorite and epidote with mm-sized albite porphyroblasts. The hanging wall rodingites are mainly composed of amphibole, epidote, and garnet. 

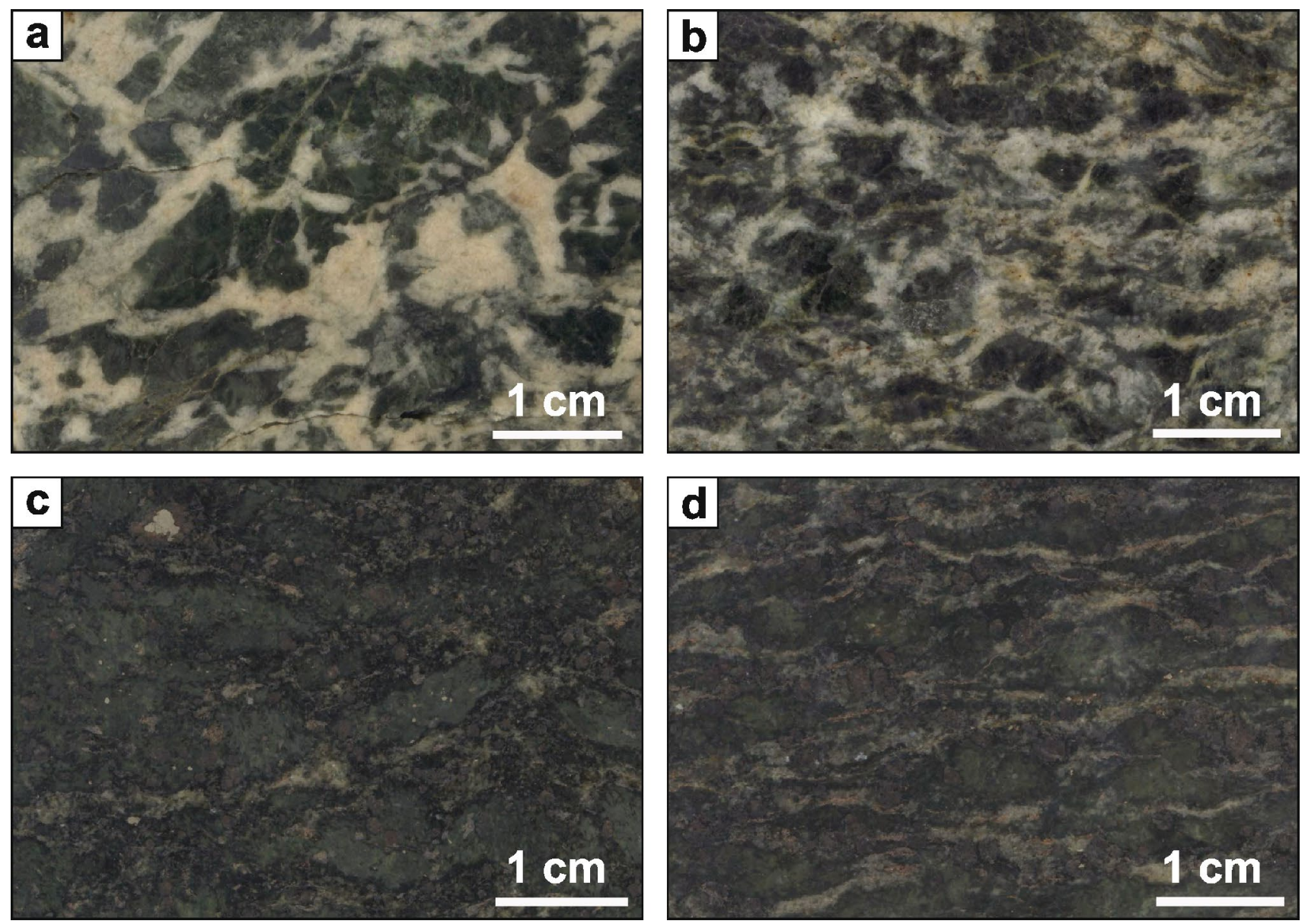

Fig. 3 Scan images of polished metagabbro and coarse eclogite samples of this study. a Preserved cumulate texture in very coarse metagabbro MG13. b Relict cumulate texture in coarse metagab-

bro MG11. c Centimeter-sized omphacite crystals are surrounded by $\mathrm{mm}$-sized garnet, clinozoisite, phengite, and quartz in coarse eclogite MG15. d Coarse-grained and foliated eclogite MG17

Among the eclogite types found in the Eclogite Zone, those with exceptional coarse-grained appearance have been interpreted as metagabbros (Miller 1977). Mineral chemistry data have not been obtained during the course of this study, but data listed in Miller (1977) show that the coarse-grained eclogites do not significantly differ from other eclogite types. In the studied samples, cmsized green omphacite crystals are surrounded by zones of mm-sized garnet, clinozoisite, phengite, and quartz. Apatite, rutile, and sulfides are accessory phases. When compared to metagabbro samples from the adjacent Glockner Nappe, the coarse eclogites are more strongly foliated and the large omphacite crystals are subhedral (Fig. 3c). Therefore, identification of magmatic protolith textures remains ambiguous. More strongly foliated eclogites still show large omphacite grains, but the coarse-grained appearance disappears (Fig. 3d). In our samples omphacite is nearly completely replaced by symplectitic amphibole, garnet displays amphibole reaction rims and biotite grew at the expense of phengite.

\section{Bulk major and trace element composition}

Studied samples are characterized by major element compositions typical for metabasic rocks in oceanic settings. The Glockner Nappe metagabbro samples are rich in $\mathrm{Mg}, \mathrm{Ca}$, and $\mathrm{Al}$ (Fig. 4a), but contain less Fe and $\mathrm{Ti}$ when compared to the adjacent greenschists (Table 2). They are depleted in most lithophile incompatible trace elements (Fig. 4b) and abundances vary strongly with $\mathrm{Al}_{2} \mathrm{O}_{3}$ content (Fig. 5a, b). Meta-leucogabbro samples are strongly enriched in $\mathrm{Al}$, consistent with their high modal abundances of feldspar and zoisite (Fig. 4a). One sample analyzed with ICP-MS displays the lowest trace element concentrations and a flat normalized REE pattern $\left(\mathrm{La}_{\mathrm{N}} / \mathrm{Yb}_{\mathrm{N}}=1.2\right)$, but very pronounced positive anomalies for $\mathrm{Sr}$ and $\mathrm{Eu}\left(\mathrm{Eu} / \mathrm{Eu}^{*}=5.9\right)$. In metagabbro samples, the positive $\mathrm{Sr}$ and $\mathrm{Eu}$ anomalies gradually disappear with decreasing $\mathrm{Al}_{2} \mathrm{O}_{3}$ and increasing $\mathrm{MgO}$ content and the patterns become more depleted in LREE $\left(\mathrm{La}_{\mathrm{N}} /\right.$ $\left.\mathrm{Yb}_{\mathrm{N}}=0.25-0.45\right)$. The HFSE Th, U, Nb, Ta, Zr, and Hf are strongly depleted in all samples $(\mathrm{Th} / \mathrm{Yb}<0.05 ; \mathrm{Nb} / \mathrm{Yb}<0.8$; 
Table 1 Representative electron microprobe analyses of silicate phases in metagabbro samples

\begin{tabular}{|c|c|c|c|c|c|c|c|c|c|c|}
\hline Sample & MG11 & MG11 & MG13 & MG13 & MG11 & MG13 & MG11 & MG13 & MG11 & MG13 \\
\hline Mineral (wt.\%) & Actinolite & $\begin{array}{l}\text { Magnesio- } \\
\text { hornblende }\end{array}$ & Actinolite & Actinolite & Albite & Albite & Chlorite & Chlorite & Phengite & Phengite \\
\hline $\mathrm{SiO}_{2}$ & 56.33 & 51.65 & 56.04 & 54.30 & 69.51 & 68.24 & 27.21 & 28.14 & 49.38 & 47.70 \\
\hline $\mathrm{TiO}_{2}$ & b.d.l & b.d.l & b.d.l & b.d.1 & b.d.l & b.d.l & b.d.l & b.d.l & 0.18 & b.d.1 \\
\hline $\mathrm{Al}_{2} \mathrm{O}_{3}$ & 2.15 & 6.18 & 2.66 & 4.64 & 19.25 & 19.53 & 20.29 & 19.40 & 25.87 & 28.98 \\
\hline $\mathrm{Cr}_{2} \mathrm{O}_{3}$ & 0.14 & 0.98 & 0.37 & 0.72 & n.a & n.a & 0.87 & 0.66 & 1.52 & b.d.1 \\
\hline $\mathrm{FeO}$ & 7.29 & 9.40 & 6.60 & 8.16 & b.d.l & b.d.l & 15.19 & 11.93 & 1.85 & 1.07 \\
\hline $\mathrm{MnO}$ & b.d.l & b.d.l & b.d.1 & b.d.l & n.a & n.a & b.d.l & b.d.l & b.d.l & b.d.1 \\
\hline $\mathrm{MgO}$ & 19.37 & 16.64 & 19.04 & 16.96 & b.d.1 & b.d.l & 22.96 & 25.16 & 2.97 & 2.28 \\
\hline $\mathrm{CaO}$ & 11.47 & 11.22 & 11.05 & 10.75 & 0.29 & 0.18 & b.d.1 & b.d.1 & b.d.1 & b.d.1 \\
\hline $\mathrm{Na}_{2} \mathrm{O}$ & 0.66 & 1.21 & 0.97 & 1.38 & 11.00 & 11.77 & b.d.l & b.d.l & 0.38 & 0.63 \\
\hline $\mathrm{K}_{2} \mathrm{O}$ & 0.11 & 0.15 & b.d.l & b.d.1 & 0.10 & b.d.l & b.d.l & b.d.l & 10.75 & 10.32 \\
\hline$\Sigma$ & 97.52 & 97.43 & 96.74 & 96.91 & 100.15 & 99.72 & 86.52 & 85.29 & 92.90 & 90.99 \\
\hline $\mathrm{Si}$ & 7.864 & 7.310 & 7.856 & 7.659 & 3.021 & 2.990 & 2.755 & 2.837 & 3.400 & 3.318 \\
\hline $\mathrm{Al}^{[\mathrm{IV}]}$ & 0.136 & 0.690 & 0.144 & 0.341 & 0.986 & 1.008 & 1.245 & 1.163 & 0.600 & 0.682 \\
\hline$\Sigma$ tetrahedron & 8.000 & 8.000 & 8.000 & 8.000 & 4.007 & 3.998 & 4.000 & 4.000 & 4.000 & 4.000 \\
\hline $\mathrm{Ti}$ & & & & & & & & & 0.009 & \\
\hline $\mathrm{Al}^{[\mathrm{IV}]}$ & 0.219 & 0.340 & 0.296 & 0.430 & & & 1.176 & 1.143 & 1.499 & 1.694 \\
\hline $\mathrm{Cr}^{3+}$ & 0.016 & 0.110 & 0.041 & 0.080 & & & 0.070 & 0.053 & 0.083 & \\
\hline $\mathrm{Fe}^{3+}$ & 0.038 & 0.328 & 0.043 & 0.126 & & & & & & \\
\hline $\mathrm{Fe}^{2+}$ & 0.696 & 0.711 & 0.641 & 0.797 & & & 1.286 & 1.006 & 0.106 & 0.062 \\
\hline $\mathrm{Mg}$ & 4.032 & 3.512 & 3.979 & 3.567 & & & 3.467 & 3.782 & 0.305 & 0.236 \\
\hline$\Sigma$ octahedron & 5.000 & 5.000 & 5.000 & 5.000 & & & 5.999 & 5.983 & 2.002 & 1.993 \\
\hline $\mathrm{Fe}^{2+}$ & 0.117 & 0.074 & 0.090 & 0.039 & & & & & & \\
\hline $\mathrm{Ca}$ & 1.715 & 1.702 & 1.660 & 1.625 & 0.013 & 0.008 & & & & \\
\hline $\mathrm{Na}$ & 0.167 & 0.224 & 0.250 & 0.336 & 0.927 & 0.999 & & & 0.051 & 0.085 \\
\hline K & & & & & 0.005 & & & & 0.945 & 0.916 \\
\hline$\Sigma$ polyhedron & 2.000 & 2.000 & 2.000 & 2.000 & 0.946 & 1.008 & & & 0.996 & 1.001 \\
\hline $\mathrm{Na}$ & 0.012 & 0.108 & 0.014 & 0.041 & & & & & & \\
\hline K & 0.019 & 0.028 & & & & & & & & \\
\hline$\Sigma$ A position & 0.031 & 0.136 & 0.014 & 0.041 & & & & & & \\
\hline \multirow[t]{4}{*}{$\Sigma$ cations } & 15.031 & 15.136 & 15.014 & 15.041 & 4.952 & 5.006 & 9.999 & 9.983 & 6.998 & 6.994 \\
\hline & & & & & An 1.40 & An 0.84 & & & Ms 59.4 & Ms 65.4 \\
\hline & & & & & Ab 98.0 & Ab 99.2 & & & Pg 5.15 & $\operatorname{Pg} 8.50$ \\
\hline & & & & & Or 0.58 & Or 0.00 & & & Cel 35.5 & Cel 26.0 \\
\hline
\end{tabular}

Amphibole: normalized to 23 oxygens; plagioclase: normalized to 8 oxygens; chlorite normalized to 14 oxygens; mica normalized to 11 oxygens An anorthite, $A b$ albite, Or orthoclase, $M s$ muscovite, $P g$ paragonite, Cel celadonite, b.d.l. below detection limit of $\sim 0.1$ wt. $\%, n . a$. not analyzed

$\mathrm{Zr} / \mathrm{Yb}<8$ ), whereas LILE are very variable and apparently unrelated to major element composition. Together with available trace element data from the literature, our data for two greenschist samples form a tight cluster of element ratios around average composition of normal mid-ocean ridge basalts (N-MORB, Fig. 4b).

The major element compositions of coarse eclogite samples, presented here (Table 2) and by Miller (1977), are very similar to greenschist facies metabasalts of the Glockner Nappe (Fig. 4a). However, they usually display more evolved compositions (i.e., lower $\mathrm{MgO}$, but higher $\mathrm{SiO}_{2}$ and $\mathrm{Na}_{2} \mathrm{O}$ ) compared to finer grained massive and banded eclogites of the Eclogite Zone (Miller 1977). On average, the eclogites are enriched in incompatible trace elements and display more variable element ratios $\left(\mathrm{La}_{\mathrm{N}} / \mathrm{Yb}_{\mathrm{N}}=2.7-6.4\right.$; $\mathrm{Th} / \mathrm{Yb}=0.37-2.1 ; \mathrm{Nb} / \mathrm{Yb}=5.0-13 ; \mathrm{Zr} / \mathrm{Yb}=45-81)$ when compared to greenschists of the Glockner Nappe $\left(\mathrm{La}_{\mathrm{N}} /\right.$ $\mathrm{Yb}_{\mathrm{N}}=0.9-1.0 ; \mathrm{Th} / \mathrm{Yb}=0.06-0.07 ; \mathrm{Nb} / \mathrm{Yb}=0.9-1.0 ; \mathrm{Zr} /$ $\mathrm{Yb}=37-40)$. Coarse eclogite sample MG17 analyzed by ICP-MS displays a trace element composition very similar to fine-grained and massive eclogite E291 (Fig. 5c, d). Both fall close to the average composition of enriched mid-ocean 


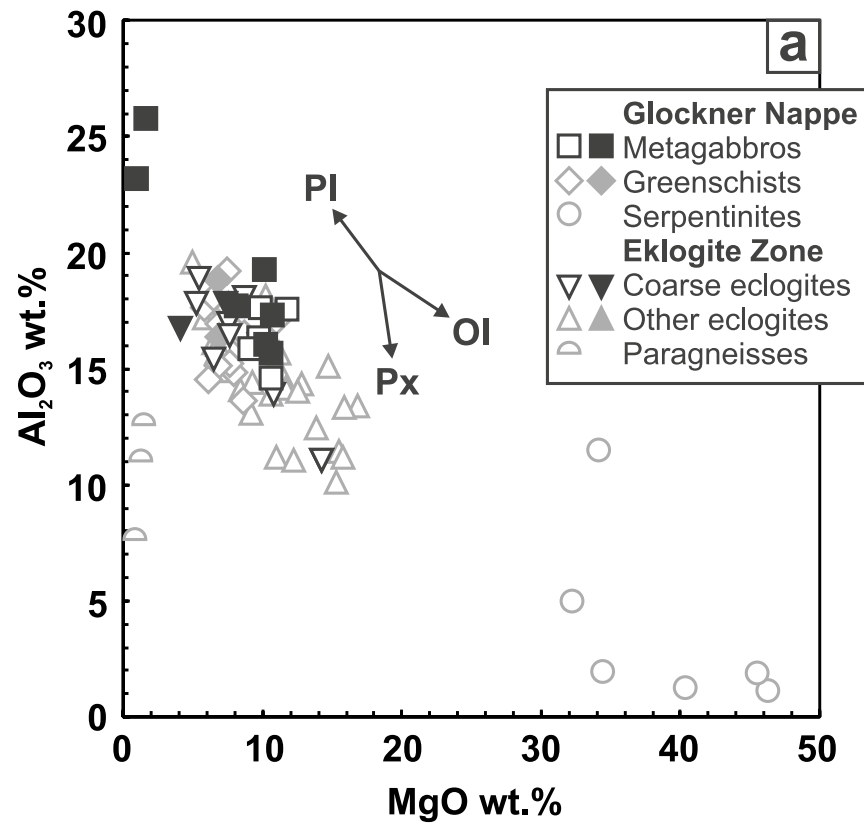

Fig. 4 Mafic, ultramafic and metasedimentary rocks of the southcentral Tauern Window. a $\mathrm{MgO}$ vs. $\mathrm{Al}_{2} \mathrm{O}_{3}$ b $\mathrm{Zr} / \mathrm{Y}$ vs. $\mathrm{Nb} / \mathrm{Y}$. Data sources: filled symbols - this study, open symbols-Höck and Miller (1987), Höck and Scharbert (1989), Meisel et al. (1997), Melcher

ridge basalts (E-MORB). In contrast, fine-grained eclogite E352 (in close contact with late-prograde dehydration segregation) is enriched in LREE $\left(\mathrm{La}_{\mathrm{N}} / \mathrm{Yb}_{\mathrm{N}}=6.4\right)$ and other HFSE $(\mathrm{Th} / \mathrm{Yb}=2.1 ; \mathrm{Nb} / \mathrm{Yb}=13 ; \mathrm{Zr} / \mathrm{Yb}=81)$ without significant anomalies.

\section{Zircons: cathodoluminescence imaging and LA-ICP- MS dating}

Zircons have been separated from greenschist facies metagabbro MG13 (Glockner Nappe) and coarse eclogite MG15 (Eclogite Zone). Short prismatic zircons in MG13 are mostly colorless and display dipyramidal growth zonation patterns (Fig. 6a). In contrast, zircons in MG15 are cloudy pink to brown and their shape is often not well preserved. Cathodoluminescence imaging reveals mainly metamict interiors and only small areas $(<20 \mu \mathrm{m})$, which display relict growth zonation patterns (Fig. 6b). For the separated ones, only those zircons with clearly visible magmatic growth zonation in MG13 have been analyzed by LA-ICP-MS (Table 3). The zircons display low and slightly variable $\mathrm{Th}, \mathrm{U}$, and $\mathrm{Pb}$ contents, but $\mathrm{Th} / \mathrm{U}$ ratios fall in the limited range from 0.29 to 0.58. Analyses of 22 individual LA-ICP-MS spots reveal ${ }^{207} \mathrm{~Pb} /{ }^{235} \mathrm{U}$ and ${ }^{206} \mathrm{~Pb} /{ }^{238} \mathrm{U}$ ages, which are normal-distributed around averages $( \pm$ SD) of $158 \pm 3 \mathrm{Ma}$ and $157 \pm 2 \mathrm{Ma}$, respectively. In a Concordia diagram, all analyzed spots define a concordant $\mathrm{U}-\mathrm{Pb}$ age of $157 \pm 2 \mathrm{Ma}$ (Fig. 7).

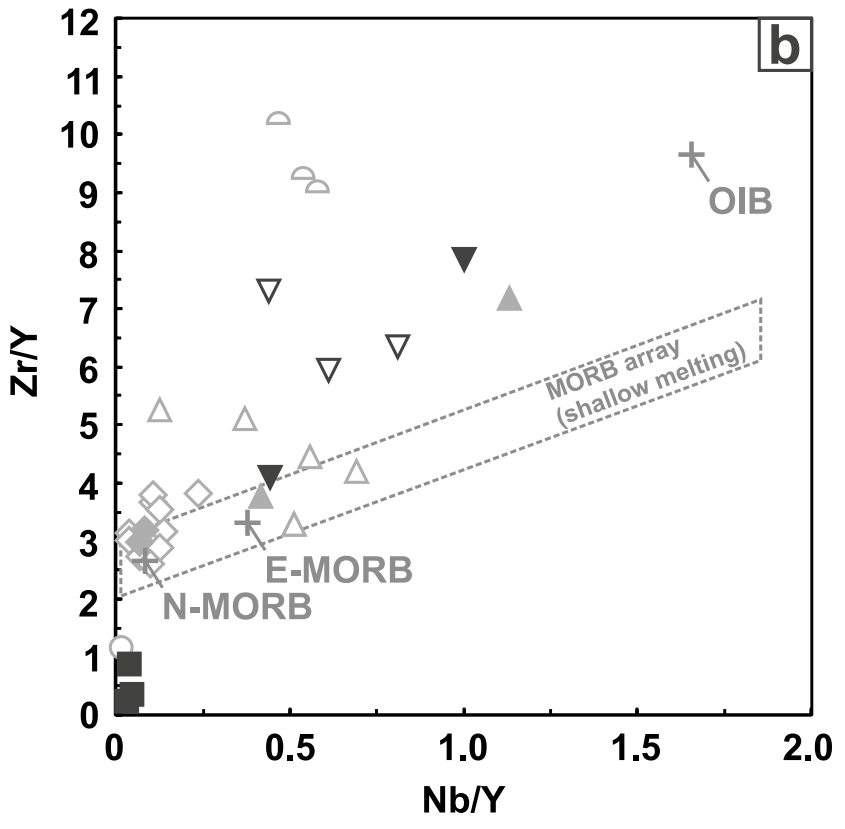

et al. (2002), Miller (1977), and Miller et al. (2007). In panel a, the effect of fractional crystallization is schematically shown. In panel b, average trace element ratios of N-MORB, E-MORB and OIB are given for comparison (Sun and McDonough 1989)

\section{Discussion}

\section{Formation of magmatic protoliths}

Based on field observations, the metagabbro had been detached from the country rocks of its original intrusion level and elongated parallel to the dominant regional layering with tectonic contacts to the surrounding metasediments (Fig. 1c). Although the continuation of the metagabbro body towards the East cannot be observed in the field, the smaller outcrop east of the Froßnitz creek is most likely related to the main body and represents either the tip of the elongated lens or a slice that had been sheared off from the main body. Smaller serpentinite lenses occurring in the same tectono-stratigraphic position (Fig. 1c) are interpreted as disrupted parts of an original ultramafic succession in the intrusion level. Together with the metagabbro, greenschists and rodingite country rocks, they form a disrupted sequence of oceanic crust. The Glockner Nappe metagabbro is characterized by a greenschist facies mineral assemblage of actinolite + clinozoisite + albite. However, the majority of the exposures preserved the texture of a coarse-grained protolith (Fig. 3a, b). Like the main mass of the gabbroic body, the deformed marginal domains display greenschist facies mineral assemblages, too. Therefore, shearing of the metagabbro body most likely happened during N-S thrusting and coeval extensional W-E shearing in the Tauern Window (e.g., Glodny et al. 2008). 


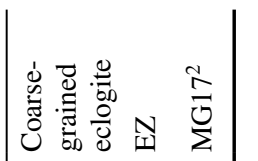

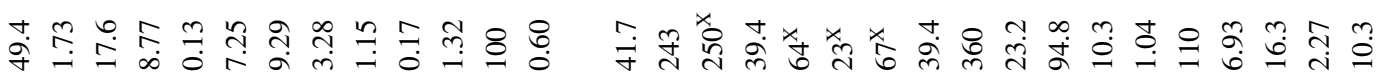

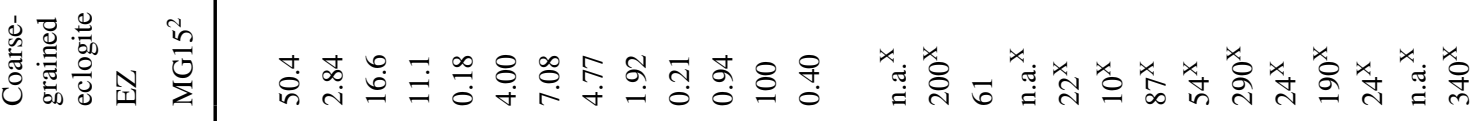

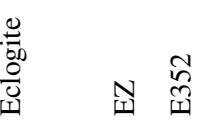

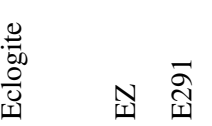 可

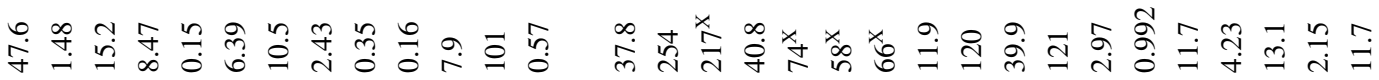

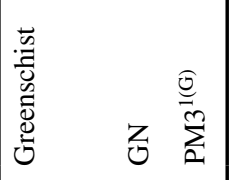

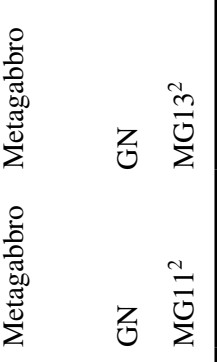

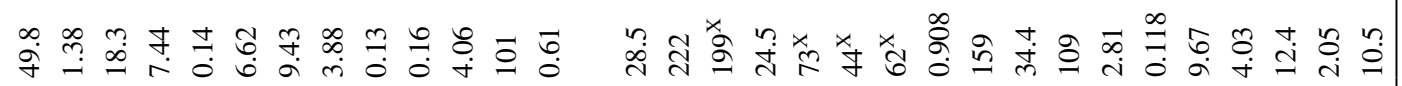

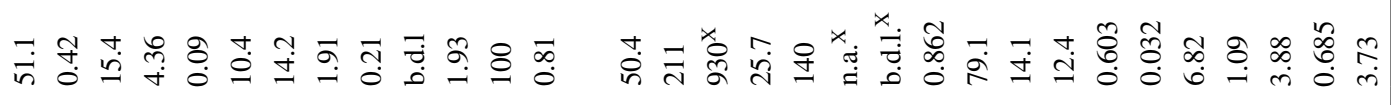

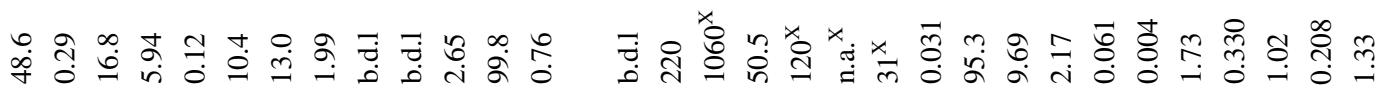

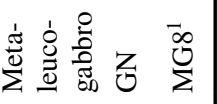

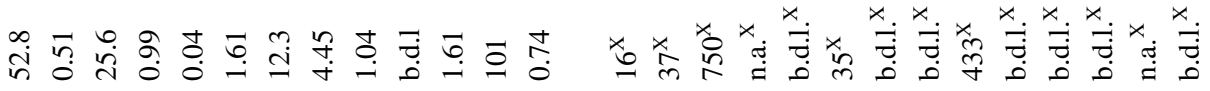

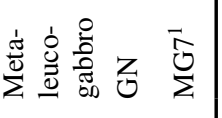

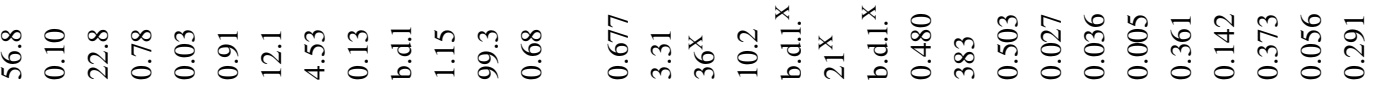

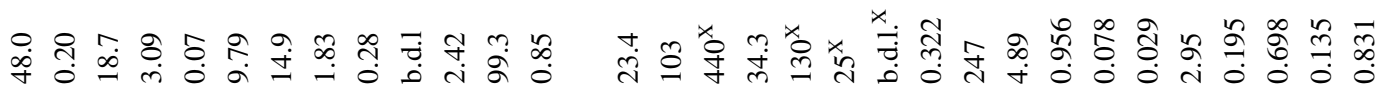 z $\overline{0}$

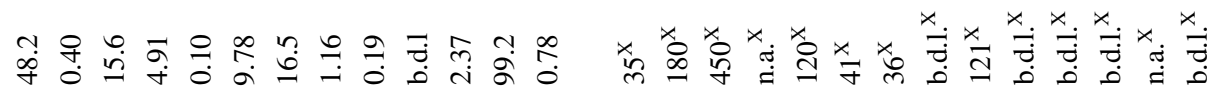

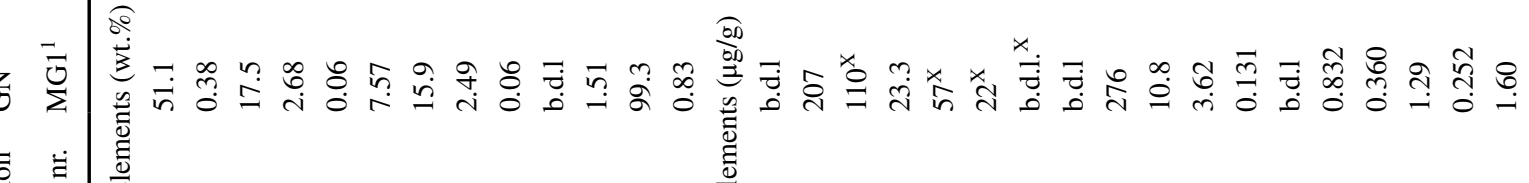

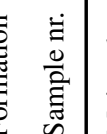

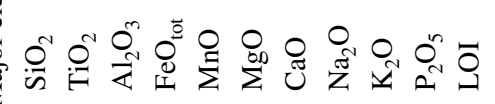 $\frac{5}{8}$

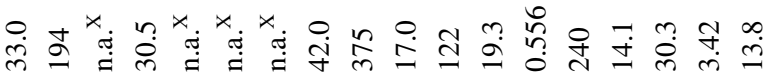

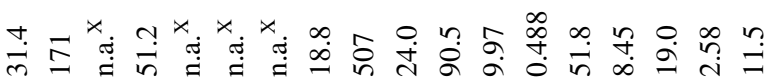 व}




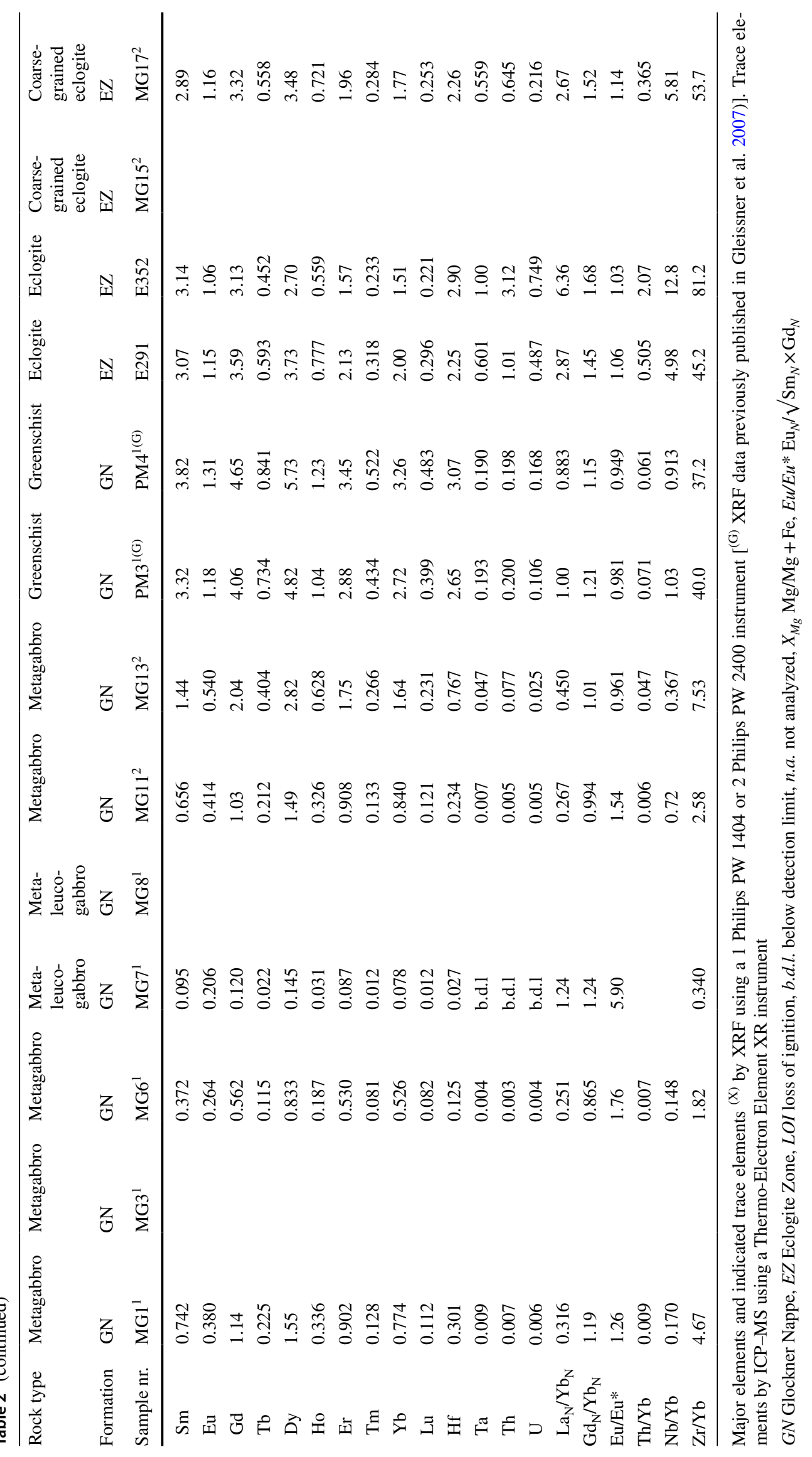



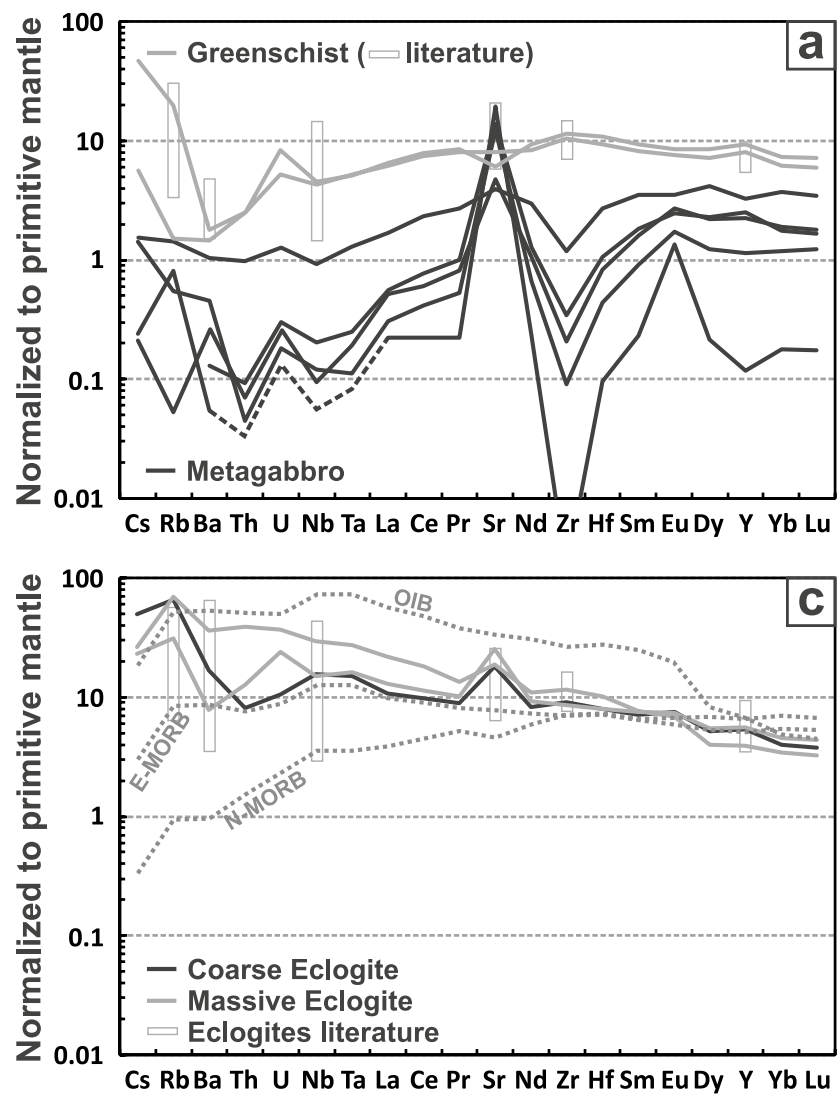

Fig. 5 Trace element composition of metabasic rocks of the southcentral Tauern Window determined by ICP-MS. a, b Metagabbro and greenschists of the Glockner Nappe. Procedural detection limit is displayed for HFSE in meta-leucogabbro MG7 (dotted line). c, $\mathbf{d}$ Coarse eclogite and massive eclogites of the Eclogite Zone. The range of

Although metagabbro and greenschists are broadly similar in their major element composition, considerable differences are observed in their trace elements (Figs. 4, 5). Metagabbro samples are generally depleted in lithophile trace elements except for elements compatible in plagioclase $(\mathrm{Eu}$ and $\mathrm{Sr}$ ) and in mafic silicates ( $\mathrm{Ni}$ and $\mathrm{Cr}$ ). Furthermore, the overall mass fractions of incompatible trace elements are inversely correlated to $\mathrm{Al}_{2} \mathrm{O}_{3}$ concentrations (Fig. 5b). Metaleucogabbro with the highest $\mathrm{Al}_{2} \mathrm{O}_{3}$ content displays a flat REE pattern with a very pronounced positive Eu anomaly, indicative of plagioclase accumulation. Together with the systematic variation of trace and major elements we interpret this observation as indicative of protolith formation by fractional crystallization and accumulation of variable amounts of plagioclase and mafic silicates, most probably augite. If this is correct, the meta-leucogabbro portions most likely represent metamorphic equivalents to zones or layers of strong accumulation of plagioclase and only minor mafic silicates. The more mafic metagabbro samples display lower $\mathrm{Al}_{2} \mathrm{O}_{3}$ contents and LREE depleted patterns $\left(\mathrm{La}_{\mathrm{N}} /\right.$ $\left.\mathrm{Yb}_{\mathrm{N}}=0.25-0.45\right)$ consistent with augite accumulation. The
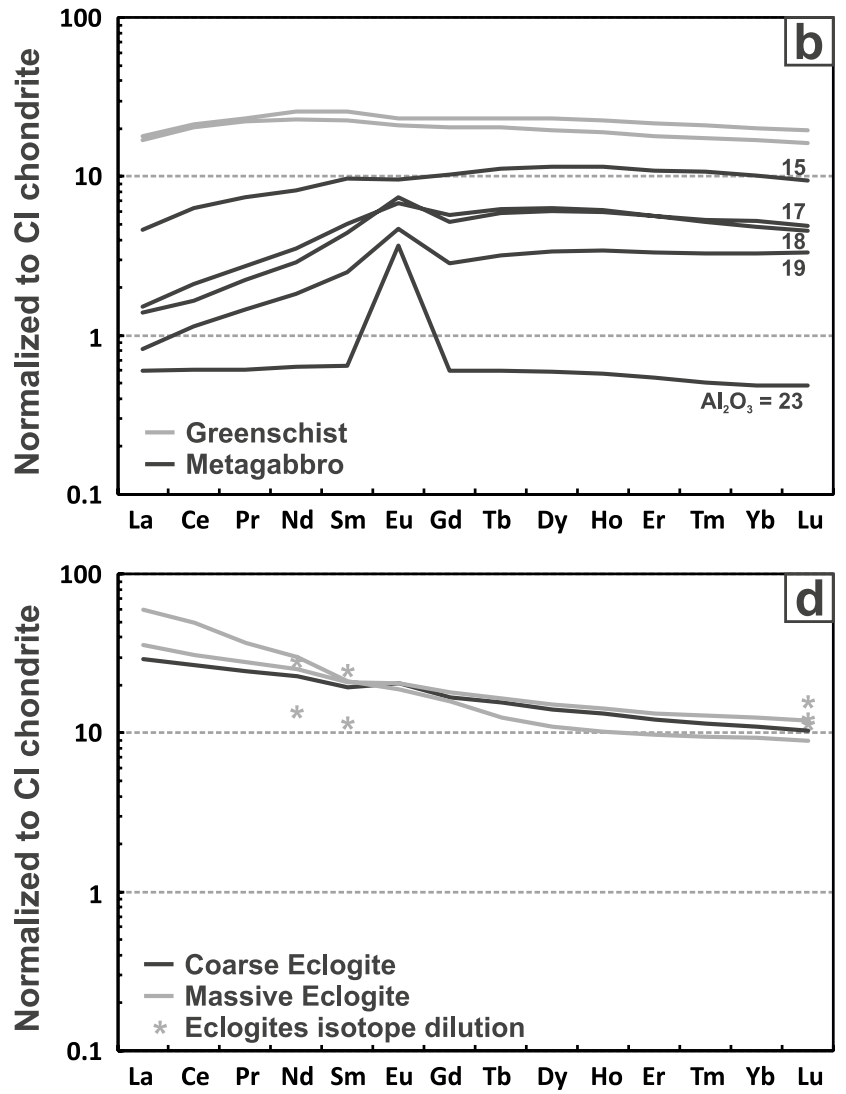

available data from the literature (references as in Fig. 3) and isotope dilution data from Nagel et al. (2013) and von Quadt et al. (1997) are shown for comparison. Abundance patterns for average N-MORB, E-MORB and OIB after Sun and McDonough (1989) and normalization values after McDonough and Sun (1995)

low $\mathrm{TiO}_{2}$ content of metagabbro samples strongly suggest that $\mathrm{Fe}$-Ti oxides were not part of the cumulate assemblage and that Ti was most likely in augite. Together with the magnesian bulk rock composition $\left(\mathrm{X}_{\mathrm{Mg}}=0.68-0.85\right)$, we suggest that the protolith of the Glockner Nappe metagabbro evolved from relatively primitive unfractionated basaltic melt and is not a Fe-Ti gabbro, which usually forms after significant fractional crystallization (e.g., Desmurs et al. 2002; Schaltegger et al. 2002).

Metagabbro with the lowest $\mathrm{Al}_{2} \mathrm{O}_{3}$ content (i.e., lowest fraction of accumulated plagioclase; sample MG13) displays a trace element pattern without pronounced anomalies, broadly parallel to studied greenschist samples (Fig. 5a, b). Therefore, we argue that it probably contains also a larger fraction of trapped intercumulus melt. The latter interpretation is also consistent with the occurrence of zircons in this sample and implies that zircon formed from the last increments of interstitial melt in pockets after accumulation of major cumulate phases. Furthermore, their dipyramidal growth zonation patterns (Fig. 6a) and $\mathrm{Th} / \mathrm{U}$ ratios $>0.2$ strongly suggest that the zircons are of magmatic and not of 
Fig. 6 Cathodoluminescence images of zircon grains separated from a greenschist facies metagabbro of the Glockner Nappe and b coarse-grained eclogite of the Eclogite Zone
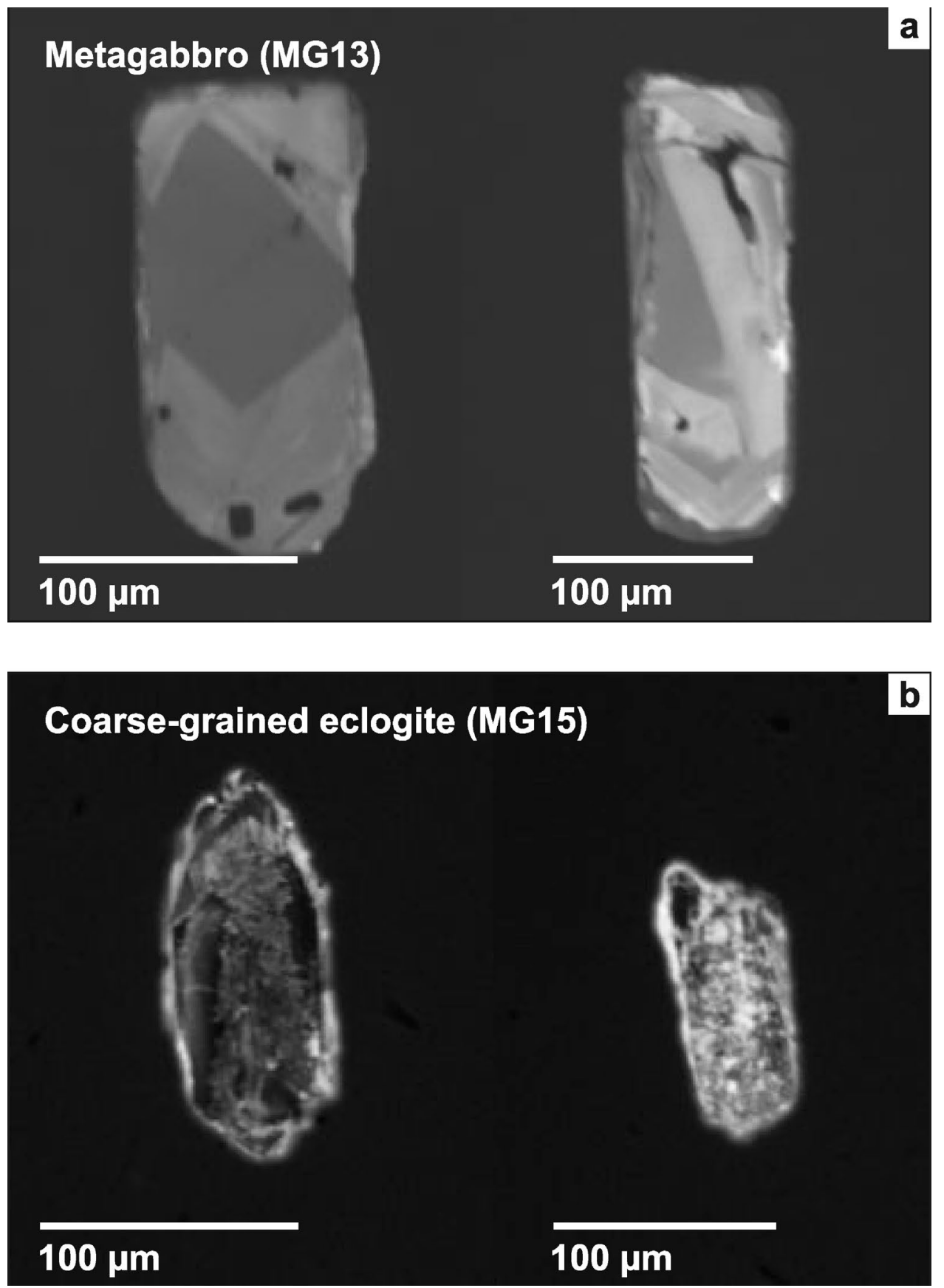

metamorphic origin (e.g., Rubatto et al. 1998; Rubatto and Hermann 2003). Based on these arguments, we interpret the concordant $\mathrm{U}-\mathrm{Pb}$ age of $157 \pm 2 \mathrm{Ma}$ (Fig. 7) as that of late magmatic crystallization of zircons in a gabbroic intrusive body, which underwent significant fractional crystallization and accumulation of plagioclase and mafic silicates. The Glockner Nappe metagabbro age falls into the range of crystallization ages obtained for most mafic intrusions in the Western and Central Alps (Fig. 8).

Coarse-grained eclogites of the Eclogite Zone have been previously interpreted as metagabbros (Miller 1977) and their occurrence was interpreted as initially concentrated at the base of the lithostratigraphic sequence (Kurz et al. 1998). However, detailed mapping by Raith et al. (1980) and this study (Fig. 1c) could not confirm a predominant occurrence of coarse-grained eclogites at the base of the Eclogite Zone (most likely they are part of larger eclogite layers). Furthermore, studied coarse-grained eclogite samples from different layers in the Eclogite Zone are very similar and relics of magmatic textures cannot be identified with confidence (Fig. 3c, d). In analogy to the actinolite crystals in the greenschist facies metagabbro of the Glockner Nappe, 


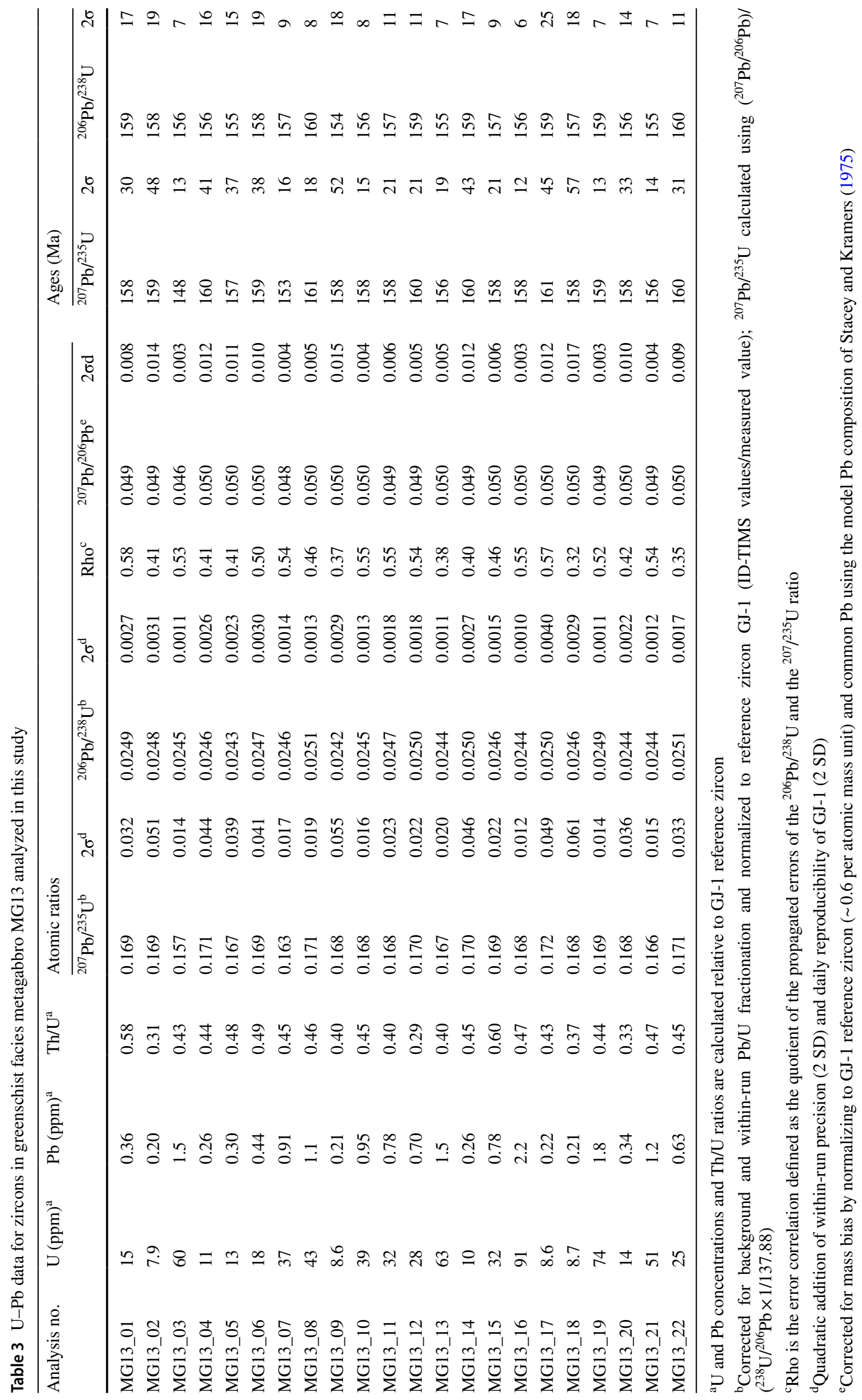




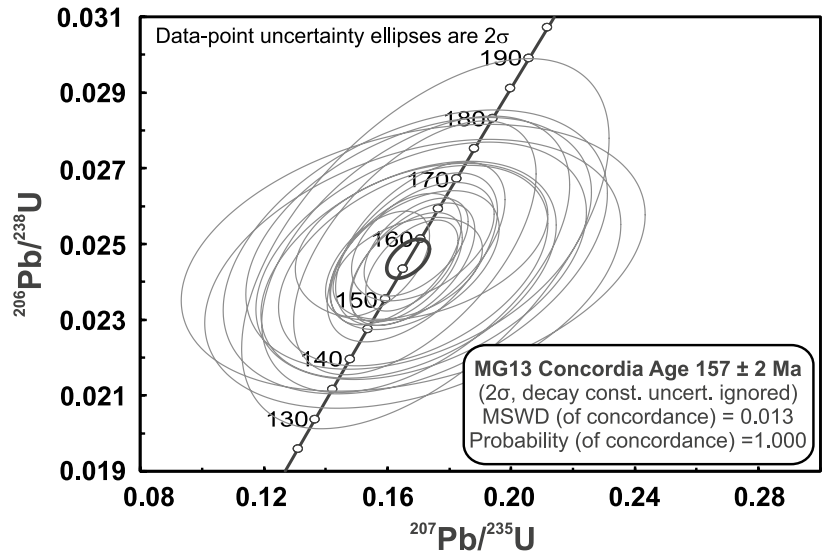

Fig. 7 Concordia diagram of U-Pb spot analyzes with LA-ICP-MS on zircons of metagabbro MG13

$\mathrm{cm}$-sized omphacite in coarse eclogites has been interpreted as pseudomorphs after augite and used as an argument to suggest coarse-grained gabbroic protoliths (Miller 1977). On the other hand, trace element data obtained for one typical coarse eclogite sample resemble patterns of fine-grained eclogite and strongly differs from gabbroic cumulate rocks like the studied metagabbro of the Glockner Nappe (Fig. 5). However, the data set is still limited and the possibilities of strong alteration of the trace element inventory due to fluid-assisted element mobility (see discussion below) and/ or precursor solidification of small plutons or dikes without significant fractional crystallization cannot be fully excluded (e.g., Desmurs et al. 2002).

\section{Tectonic setting and source of magmatic protoliths}

Based on relict pillow structures (Holland and Norris 1979), trace elements which are considered as immobile (Bickle and Pearce 1975), and their isotopic composition (Höck and Scharbert 1989), the Glockner Nappe greenschists are interpreted as metamorphosed ocean-floor basalts. In most classification schemes, the greenschists indicate MORB composition and many authors (Bickle and Pearce 1975; Höck and Koller 1989; Höck and Miller 1987; Höck and Scharbert 1989) favor a formation from depleted mantle. In contrast, the affiliation of the metabasic rocks of the Eclogite Zone is less well constrained. Their composition apparently reflects a less depleted source or higher degree of source melting (Höck and Miller 1987). Furthermore, it has been suggested that the composition of the mantle source which supplied melts to the transitional crust located between the European continental margin and the opening Penninic ocean basin might have changed over time (e.g., Höck and

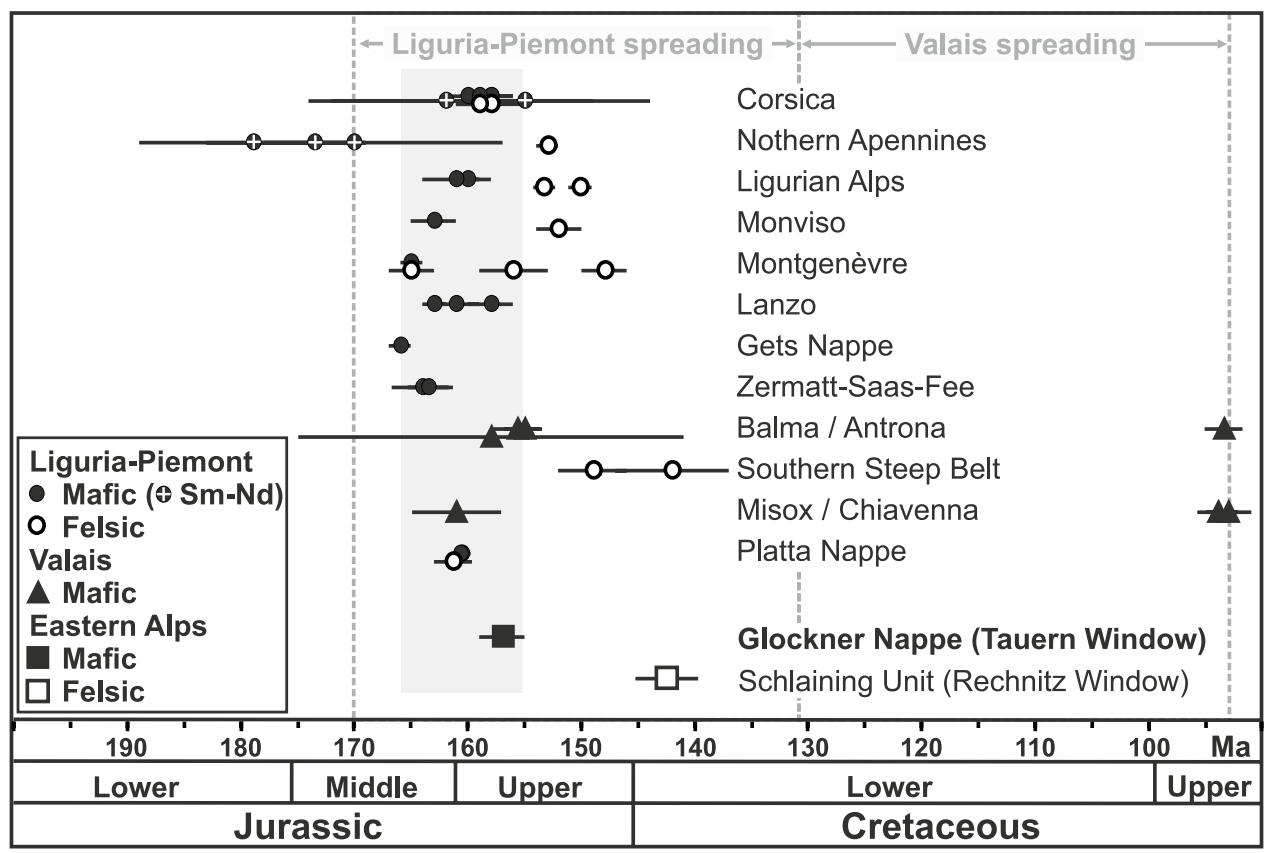

Fig. 8 Crystallization age data for mafic and felsic intrusions into oceanic lithosphere along the Corsica-Apennine-Alpine mountain belt; data are concordant U-Pb zircon ages (Bill et al. 2001; Borsi et al. 1996; Costa and Caby 2001; Froitzheim and Rubatto 1998; Kaczmarek et al. 2008; Li et al. 2013, 2015; Liati and Froitzheim 2006; Liati et al. 2003, 2005; Lombardo et al. 2002; Neubauer et al. 2019; Rubatto and Hermann 2003; Rubatto and Scambelluri 2003;
Schaltegger et al. 2002; Stucki et al. 2003) and internal Sm-Nd isochron ages (Rampone et al. 2009; Tribuzio et al. 2004). Suggested age ranges from the literature for sea-floor spreading in the Liguria-Piemont and Valais domain of the Alpine Tethys (Handy et al. 2010) and dominantly mafic plutonic activity (gray field, Manatschal and Müntener 2009) are shown for comparison 
Koller 1989; Kurz et al. 1998). However, correct classification of metabasic rocks is possibly hampered by metamorphic element transport (Miller 1977), especially under high-pressure fluid-rock interaction (Brunsmann et al. 2000) prevalent during peak metamorphism in the Eclogite Zone.

In a $\mathrm{Th} / \mathrm{Yb}$ vs. $\mathrm{Nb} / \mathrm{Yb}$ diagram, available data from the literature and this study plot onto the array of oceanic basalts (Pearce 2008, not shown), but display increasing ratios from greenschists towards eclogite. Akin to the classification scheme of Pearce (2008), in Fig. 4b, trace elements of different compatibility are compared. We use $\mathrm{Zr}$ instead of $\mathrm{Ti}$, because it is less mobile during subduction zone metamorphism (Gao et al. 2007) and Y instead of Yb, because more data are available. Greenschists from different localities fall in a restricted range around the average of modern-day N-MORB compositions. This argues for only minor alteration of $\mathrm{Zr} / \mathrm{Y}$ and $\mathrm{Nb} / \mathrm{Y}$ ratios during Alpine metamorphism and preservation of depleted mantle source characteristics. Consistently, the trace element patterns of studied greenschist samples display increasing depletions towards incompatible elements and only minor disturbances for very fluid mobile elements like $\mathrm{Cs}$ and $\mathrm{Rb}$ (Fig. 5a). Trace element patterns of metagabbro samples are governed by mass fractions of cumulate phases, but also by the amount of trapped interstitial liquid (see discussion above). The sample with the least indication of cumulate plagioclase (i.e., no anomaly in $\mathrm{Eu}$ and $\mathrm{Sr}$ ) displays a trace element pattern similar to greenschist samples (Figs. 5a, b). Therefore, we argue that the magmatic protolith of the Glockner Nappe metagabbro formed from a melt similarly depleted in incompatible trace elements. This interpretation is also consistent with low mass fractions of $U$ and $T h$ in analyzed zircons (Table 3). All metagabbro samples analyzed in our study display depletions in $\mathrm{Zr}$ and $\mathrm{Hf}$, which can be attributed to the coarse nature of the rocks and the heterogeneous distribution of zircon.

Major and trace element composition of the Glockner Nappe metagabbro is similar to $\mathrm{Mg}$-gabbros described in ophiolitic sequences of the Western and Central Alps. There, gabbroic dikes and/or km-sized bodies are described as intrusions into exhumed, serpentinized subcontinental mantle in ocean-continent transition settings (Desmurs et al. 2002; Kaczmarek et al. 2008). For the Glockner Nappe metagabbro, further constraints on its tectonic setting can be gained from spatially related metamorphic ultramafic rocks and metabasalts. A serpentinite in the Dorfertal, a valley east of the Froßnitztal, is one of the largest in the area and occurs together with smaller serpentinite lenses west of the metagabbro in the same tectono-stratigraphic position within calcareous metasediments (Fig. 1c). Another larger occurrence of meta-ultramafic rocks, the Mailfroßnitz serpentinite, is situated a few $\mathrm{km}$ east of the metagabbro in a similar stratigraphic position (Melcher et al. 2002). Both serpentinites are harzburgitic and are interpreted as ultramafic cumulates (Meisel et al. 1997; Melcher et al. 2002). Available Re-Os data for the Dorfertal serpentinite reveal a depletion in Re and strongly subchondritic ${ }^{187} \mathrm{Os} /{ }^{188} \mathrm{Os}$ ratios (Meisel et al. 1997). Since known low-temperature processes during serpentinization cannot produce such low ${ }^{187} \mathrm{Os} /{ }^{188} \mathrm{Os}$ ratios (Becker and Dale 2016), Re-depletion must have occurred much earlier than tectonic emplacement and the system must have been isolated from the convecting mantle for long time (Meisel et al. 1997). Such characteristics are typically observed in fragments of exhumed subcontinental lithospheric mantle that have undergone Proterozoic melt extraction (Becker and Dale, 2016). The derivation of the Dorfertal serpentinite from subcontinental lithospheric mantle contradicts coeval formation of the ultramafic cumulates and basic rocks in Mesozoic oceanic lithosphere, but is a strong similarity to the magma-poor ocean-continent transition of exhumed subcontinental mantle rocks and associated magmatic and sedimentary rocks observed in many ophiolitic sequences of the Western and Central Alps (Becker and Dale, 2016; Manatschal and Müntener 2009).

The Eclogite Zone is commonly interpreted as part of the passive European continental margin (e.g., Kurz et al. 1998; Miller et al. 2007), but considered most likely as not being part of the Glockner Nappe system (Kurz et al. 1998; Schmid et al. 2013). Consistent with available data from the literature, our new trace element data show that metabasic rocks of the two units are considerably different. Whereas the greenschists of the Glockner Nappe consistently show N-MORB-like affinities, the metabasic rocks of the Eclogite Zone display much more variable compositions ranging from average E-MORB towards higher enrichments in incompatible trace elements (Figs. 4b, 5c). The large variation does not correlate with major element composition or grain size, but can be explained most likely with fluid-assisted trace element mobility during peak metamorphic conditions. Brunsmann et al. (2000) demonstrated that trace elements like $\mathrm{Nb}$ and $\mathrm{Zr}$, usually considered as immobile, can vary considerably due to high-pressure fluid-rock interaction over a distance of $10 \mathrm{~s}$ of centimeters. In the latter study, observed variations of $\mathrm{Nb} / \mathrm{Y}$ and $\mathrm{Zr} / \mathrm{Y}$ ratios fall above the MORB array similar to most of the eclogite samples (Fig. 4b). Furthermore, when compared to available data for neighboring siliciclastic metasediments (Miller 1977), fluid-assisted trace element exchange could explain elevated $\mathrm{Zr} / \mathrm{Y}$ ratios and also variations in other HFSE. However, we note that none of the eclogite samples plot in the range of Glockner Nappe metabasalts (Fig. 4b) and that observed patterns for less mobile trace elements are generally smooth (Figs. 5c, d). Therefore, we argue for different initial trace element abundances between the two metabasic suites. Furthermore, separated zircons from a coarse-grained eclogite sample display metamict interiors (Fig. 6b) and could not be dated. 
Such metamictization is apparently consistent with generally higher $\mathrm{U}$ contents in metabasic samples from the Eclogite Zone (Fig. 5). The above geochemical indicators suggest that the Eclogite Zone metabasic rocks are generally more enriched in incompatible trace elements than the depleted samples of the Glockner Nappe. This interpretation of the Eclogite Zone metabasites is consistent with assimilation of pre-Mesozoic continental basement by depleted mantle melts as indicated by recent $\mathrm{Rb}-\mathrm{Sr}, \mathrm{Lu}-\mathrm{Hf}$, and $\mathrm{Sm}-\mathrm{Nd}$ isotopic data (Gleissner et al. 2007; Glodny et al. 2005; Nagel et al. 2013; von Quadt et al. 1997).

\section{Rifting and sea-floor spreading in the Alpine Tethys}

\section{Western Alps}

The age of the oceanic crust of the former Alpine Tethys has been constrained by different isotope and stratigraphic methods. Here, we focus on in situ dating of magmatic zircons from mafic and felsic intrusions from the literature (Fig. 8). Concordant $\mathrm{U}-\mathrm{Pb}$ data from zircons showing typical oscillatory magmatic zoning, and $\mathrm{Th} / \mathrm{U}$ ratios in the range of magmatic zircon are interpreted as representative of crystallization ages of respective intrusions or dikes. Unzoned zircons or zircon domains commonly yield discordant $\mathrm{U}-\mathrm{Pb}$ data and younger apparent ages which most likely reflect $\mathrm{Pb}$-loss during Alpine metamorphism (e.g., Lombardo et al. 2002). Sm-Nd internal isochron ages (Fig. 8) are considered only when in situ $\mathrm{U}-\mathrm{Pb}$ zircon ages are not available, because these ages sometimes have higher uncertainties because of limited fractionation of $\mathrm{Sm} / \mathrm{Nd}$ ratios between mineral phases in gabbroic intrusions (e.g., Rampone et al. 1998) and, like $\mathrm{K}-\mathrm{Ar}$, Sm-Nd systematics might also be affected by metamorphic overprint.

Magmatic rocks related to rifting and spreading had been dated previously in the Western and Central Alps, Apennines and Corsica. According to the available data magmatic activity in the Liguria-Piemont oceanic domain may have lasted from 170 to $140 \mathrm{Ma}$. U-Pb zircon data for most ophiolitic gabbros show an even shorter time span from 166 to $155 \mathrm{Ma}$ whereas more differentiated intrusions (i.e., diorite, plagiogranite, albitite) are coeval or postdate mafic intrusions (Fig. 8). In most localities, detailed geochemical and structural analyses reveal that small bodies of mafic melt with MORB characteristics intruded already serpentinized mantle rocks with older depletion ages (e.g., Lombardo et al. 2002; Rampone et al. 1998; Schaltegger et al. 2002; Tribuzio et al. 2004). The latter association is interpreted as remnants of former ocean-continent transition zones where subcontinental mantle rocks were exhumed and serpentinized in a magma-poor slow-spreading regime (e.g., Manatschal and Müntener 2009). Scarce occurrences of mafic intrusions in isotopic equilibrium with mantle rocks like in the Corsica ophiolite (Rampone et al. 2009) are interpreted as representing more developed oceanic domains $(\mathrm{Li}$ et al. 2015; Manatschal and Müntener 2009). Although in Alpine ophiolites, oceanic basalts and their metamorphic equivalents are more widespread than plutonic rocks, determining their crystallization ages is commonly hampered by the absence of zircon, smaller grain size and/or metamorphic overprint. However, radiolarian biostratigraphy shows that the time span of pelagic sediment deposition on top of oceanic basalts overlap with $\mathrm{U}-\mathrm{Pb}$ ages of plutonic activity (e.g., Balestro et al. 2019; Bill et al. 2001; Lombardo et al. 2002; Principi et al. 2004). This strongly suggests broadly coeval extrusion of oceanic basalts and plutonic activity and further supports the existence of a slow-spreading ridge in the Liguria-Piemont oceanic basin (Manatschal and Müntener 2009).

In contrast to ophiolites ascribed to the Liguria-Piemont ocean, the time of rifting and sea-floor spreading in the Valais ocean domain and the structure and composition of its crust are less well constrained. Based on structural and sedimentological arguments opening of the Valais ocean basin started north of the Briançonnais in the Late Jurassic to Early Cretaceous (Stampfli et al. 1998). Recent U-Pb zircon data for different lithologies with oceanic affinity reveal a bimodal distribution of ages (Fig. 8). The older ages, overlapping with the time of dominant mafic plutonic activity in the Liguria-Piemont domain, are explained by spreading within Jurassic Liguria-Piemont oceanic crust (Liati et al. 2003 , 2005). However, the radiometric ages clearly indicate that these rocks formed in the Liguria-Piemont oceanic basin and were eventually re-rifted during the later Valais ocean opening. The younger ages are interpreted as representing late stages of spreading in the Valais ocean (Liati and Froitzheim 2006; Liati et al. 2003). The apparent gap of 50 Ma remains enigmatic, but might reflect either episodic spreading or complete subduction of Early Cretaceous ocean floor (Liati and Froitzheim 2006). The tectonic setting of dated Valais oceanic crust fragments is generally interpreted as that of a basin floored by subcontinental mantle exhumed from below the adjacent European and Briançonnais margins. The Valais ophiolites are derived from depleted mantle sources (Liati and Froitzheim 2006; Liati et al. 2003 and references therein), similar to most Liguria-Piemont ophiolites (Manatschal and Müntener 2009).

\section{Eastern Alps}

Tracing the continuation of the two distinct oceanic basins from the Western and Central Alps towards the East is complicated due to coverage by Austroalpine nappes and scarcity of robust age constraints. This led to contrasting interpretations on the nature of ophiolite units exposed in tectonic windows of the Eastern Alps. In the Engadine 
Window, the Briançonnais nappe facilitates the correlation with the Central Alps and most authors agree that remnants of both oceanic basins are exposed (e.g., Bertle 2004; Kurz 2006; Schmid et al. 2004). Correlation of metasedimentary units towards the East is complicated by the absence of stratigraphically useful microfossils in the Glockner Nappe (Bertle 2004) and correlations based on similarities of volcano-sedimentary successions remain ambiguous (Kurz 2006). Therefore, the question if remnants of Valais oceanic crust, Liguria-Piemont oceanic crust or both are exposed in the Tauern Window and the Rechnitz Window group is still debated (e.g., Kurz 2006; Schmid et al. 2004, 2013).

To constrain the affiliation of the Glockner Nappe ophiolitic sequence the finding of a $157 \pm 2 \mathrm{Ma}$ (Late Jurassic) crystallization age for the magmatic precursor of the metagabbro is an important step forward. To our knowledge, this is the first radiometric age determination for the formation of Alpine Tethys ocean floor in the Tauern Window. Emplacement ages of mafic plutons in the Liguria-Piemont domain do not greatly differ along the Corsica-Apennine-Alpine mountain chain (see discussion above) and the Glockner Nappe gabbro intrusion age falls exactly in this age range (Fig. 8). Furthermore, a similar tectonic setting as for most Liguria-Piemont ophiolites can be reconstructed from the regional geology and isotopic data from the literature; serpentinized subcontinental mantle was intruded by a small mafic pluton from a depleted asthenospheric mantle source. These two key observations strongly suggest that the Glockner Nappe was part of the same oceanic basin and was formed in a similar ocean-continent transition setting as the Liguria-Piemont ophiolites in the Western and Central Alps. In principle the ocean-continent transition setting could also be consistent with a Valais affiliation (see discussion above), but the Late Jurassic gabbro intrusion age excludes its formation during Cretaceous Valais ocean spreading. Following the above reasoning, we argue that the magmatic protolith of the Glockner Nappe metagabbro and its disrupted ophiolite sequence formed during the Late Jurassic in the eastward extension of the Liguria-Piemont branch of the Alpine Tethys.

For metabasic rocks of the Eclogite Zone, no formation age could be determined in the present study and the limited Lu-Hf data available are regarded as inconclusive with respect to the time of formation of their protoliths (Nagel et al. 2013). However, following the correlation of Penninic and Subpenninic units in the Tauern and Engadine Window, the continental Rote-Wand-Modereck Nappe (sandwiched between Glockner Nappe and Eclogite Zone, Fig. 1b, c) is interpreted as distal European continental margin (i.e., Subpenninic; Kurz 2006). The latter interpretation is entirely consistent with our finding of Late Jurassic ocean floor formation in the hanging wall Glockner Nappe (i.e., Southpenninic). Metabasic rocks in the Eclogite Zone structurally below the Rote-Wand-Modereck Nappe, display characteristics of depleted mantle melting and assimilation of preexisting continental basement (see discussion above). The observed characteristics might reflect a later rifting phase, which separated crustal slices of the distal European margin. Alternatively, the Eclogite Zone might represent an extension of the Late Jurassic ocean basin separated by the RoteWand-Modereck Nappe as a small extensional allochthon as discussed by Kurz (2006) and Groß et al. (2020). However, without robust age constraints for the formation of eclogite protoliths the time of the latter rifting event and its relation to oceanic basins remains speculative.

East of the Tauern Window, Penninic units are exposed in the Rechnitz Window group (Fig. 1a). Recently, Neubauer et al. (2019) reported a plagiogranite protolith age of $142 \mathrm{Ma}$, interpreted to represent the age of oceanic spreading. Since this age is apparently younger than the Liguria-Piemont ophiolites, but older than the remnants of the Valais ocean the authors do not consider a relation with oceanic spreading in the Penninic basin. However, the latter formation age is coeval with similar plagiogranite intrusion ages in the Central Alps (Fig. 8). Available data from the Western and Central Alps show that felsic intrusions into the oceanic lithosphere of the Liguria-Piemont domain often significantly postdate mafic intrusions. Although a detailed discussion of the Rechnitz Window group is beyond the scope of this study an Early Cretaceous plagiogranite age does not necessarily preclude a correlation of ophiolitic units in the Tauern Window and Rechnitz Window group.

\section{Summary and conclusions}

Based on textural and compositional characteristics, we conclude that the coarse-grained prasinite body in the Froßnitztal originated from a coarse-grained gabbroic intrusion into a segment of oceanic crust which later formed the Glockner Nappe. The trace element composition of different metagabbro samples clearly reveals its magmatic formation by fractional crystallization and accumulation of plagioclase and mafic silicates from a depleted melt composition. Greenschists of the Glockner Nappe display similar trace element patterns consistent with asthenospheric depleted mantle sources for both the metabasalts and the metagabbro. Available data from the literature indicate the presence of depleted subcontinental lithospheric mantle in the intrusion level of the protolith. The latter association strongly suggests the intrusion of a small gabbro pluton in an ocean-continent transition setting with exhumed and serpentinized lithospheric mantle, similar to many ophiolitic sequences in the Western and Central Alps.

The concordant $\mathrm{U}-\mathrm{Pb}$ age of $157 \pm 2 \mathrm{Ma}$, determined here from zircon grains with magmatic growth zonation, 
is interpreted as crystallization age of the gabbro protolith. Consequently, the formation of the volcano-sedimentary succession of the Glockner Nappe is interpreted as Late Jurassic. The latter age constraint is inconsistent with its formation during Cretaceous spreading of the Valais oceanic, but coeval with the time of dominant mafic plutonism in the Liguria-Piemont domain of the Alpine Tethys. Together with the similarity in tectonic setting, we conclude that the Glockner Nappe of the Tauern Window is a remnant of the eastward extension of the Liguria-Piemont ocean basin. This finding implies that remnants of the Valais ocean are far less abundant in the Eastern Alps than suggested in some recent paleogeographic reconstructions.

Coarse eclogites of the Eclogite Zone are most likely not metamorphic equivalents of gabbroic intrusions into oceanic crust as suggested in earlier studies (Miller 1977; Kurz et al. 1998). Incompatible lithophile trace elements reveal considerable variability among different eclogite types, but do not support cumulate gabbro precursors for the coarse-grained eclogite type. The age of their formation could not be retrieved during this study, however, geochemical characteristics reveal significant differences between metabasic rocks of the Eclogite Zone and the Glockner Nappe. Whereas the Glockner Nappe metagabbro and metabasalts reveal clear indications of their derivation from a depleted mantle source and emplacement in an oceanic-continent transition setting, formation of metabasic rocks of the Eclogite Zone involved depleted mantle melting and significant assimilation of crustal material in a continental margin setting.

Supplementary Information The online version contains supplementary material available at https://doi.org/10.1007/s00531-021-02075-z.

Acknowledgements We are indebted to J. Glodny for support and access to the mineral separation facilities at GFZ Potsdam. Furthermore, we would like to thank P. Marsiske for the XRF measurements and F. Galbert for electron microprobe analyses at TU Berlin, and R. Milke for help with the electron microprobe analyses and K. Schneider and E. Hoffmann for help with trace element measurements at FU Berlin. J. Pleuger provided helpful comments to an earlier version of the manuscript. We acknowledge thoughtful reviews by W. Kurz and the topic editor N. Froitzheim, which helped to improve the manuscript.

Funding Open Access funding enabled and organized by Projekt DEAL. Not applicable.

Availability of data and materials Data in the manuscript and appendix will be published as replication data set in Pangaea.

Code availability Not applicable.

\section{Declarations}

Conflict of interest The authors declare no conflict of interest.

Ethics approval Not applicable.
Consent to participate Not applicable.

Consent for publication Not applicable.

Open Access This article is licensed under a Creative Commons Attribution 4.0 International License, which permits use, sharing, adaptation, distribution and reproduction in any medium or format, as long as you give appropriate credit to the original author(s) and the source, provide a link to the Creative Commons licence, and indicate if changes were made. The images or other third party material in this article are included in the article's Creative Commons licence, unless indicated otherwise in a credit line to the material. If material is not included in the article's Creative Commons licence and your intended use is not permitted by statutory regulation or exceeds the permitted use, you will need to obtain permission directly from the copyright holder. To view a copy of this licence, visit http://creativecommons.org/licenses/by/4.0/.

\section{References}

Agard P (2021) Subduction of oceanic lithosphere in the Alps: selective and archetypal from (slow-spreading) oceans. Earth-Sci Rev 214:103517

Balestro G, Festa A, Dilek Y (2019) Structural architecture of the Western Alpine Ophiolites, and the Jurassic seafloor spreading tectonics of the Alpine Tethys. J Geol Soc 176:913-930

Becker H, Dale CW (2016) Re-Pt-Os isotopic and highly siderophile element behavior in oceanic and continental mantle tectonites. Rev Miner Geochem 81(1):369-440

Bertle RJ (2004) The sedimentary record of North Penninic Schistes Lustrés of the Lower Engadine Window and its correlation to the Tauern Window (Eastern Alps). Jahrbuch Der Geologischen Bundesanstalt Wien 144:165-171

Bickle M, Pearce J (1975) Oceanic mafic rocks in the Eastern Alps. Contrib Miner Petrol 49:177-189

Bill M, O’Dogherty L, Guex J, Baumgartner PO, Masson H (2001) Radiolarite ages in Alpine-Mediterranean ophiolites: constraints on the oceanic spreading and the Tethys-Atlantic connection. Geol Soc Am Bull 113:129-143

Borsi L, Schärer U, Gaggero L, Crispini L (1996) Age, origin and geodynamic significance of plagiogranites in lherzolites and gabbros of the Piedmont-Ligurian ocean basin. Earth Planet Sci Lett 140:227-241

Brunsmann A, Franz G, Erzinger J, Landwehr D (2000) Zoisite-and clinozoisite-segregations in metabasites (Tauern Window, Austria) as evidence for high-pressure fluid-rock interaction. J Metamorph Geol 18:1-22

Costa S, Caby R (2001) Evolution of the Ligurian Tethys in the Western Alps: $\mathrm{Sm} / \mathrm{Nd}$ and $\mathrm{U} / \mathrm{Pb}$ geochronology and rare-earth element geochemistry of the Montgenèvre ophiolite (France). Chem Geol 175:449-466

Desmurs L, Müntener O, Manatschal G (2002) Onset of magmatic accretion within a magma-poor rifted margin: a case study from the Platta ocean-continent transition, eastern Switzerland. Contrib Miner Petrol 144:365-382

Franz G, Spear FS (1983) High pressure metamorphism of siliceous dolomites from the central Tauern Window, Austria. Am J Sci 283:396-413

Frei D, Gerdes A (2009) Precise and accurate in situ U-Pb dating of zircon with high sample throughput by automated LA-SF-ICPMS. Chem Geol 261:261-270

Froitzheim N, Manatschal G (1996) Kinematics of Jurassic fifting, mantle exhumation, and passive-margin formation in the 
Austroalpine and Penninic nappes (eastern Switzerland). GSA Bull 108:1120-1133

Froitzheim N, Rubatto D (1998) Continental breakup by detachment faulting: field evidence and geochronological constraints (Tasna nappe, Switzerland). Terra Nova 10:171-176

Gao J, John T, Klemd R, Xiong X (2007) Mobilization of Ti-NbTa during subduction: evidence from rutile-bearing dehydration segregations and veins hosted in eclogite, Tianshan, NW China. Geochim Cosmochim Acta 71:4974-4996

Gleissner P, Glodny J, Franz G (2007) Rb-Sr isotopic dating of pseudomorphs after lawsonite in metabasalts from the Glockner nappe, Tauern Window, Eastern Alps. Eur J Mineral 19:723-734

Glodny J, Ring U, Kühn A, Gleissner P, Franz G (2005) Crystallization and very rapid exhumation of the youngest Alpine eclogites (Tauern Window, Eastern Alps) from $\mathrm{Rb} / \mathrm{Sr}$ mineral assemblage analysis. Contrib Miner Petrol 149:699-712

Glodny J, Ring U, Kühn A (2008) Coeval high-pressure metamorphism, thrusting, strike-slip, and extensional shearing in the Tauern Window, Eastern Alps. Tectonics 27(4). https://doi.org/ 10.1029/2007TC002193

Groß P, Handy MR, John T, Pestal G, Pleuger J (2020) Crustalscale sheath folding at HP conditions in an exhumed Alpine subduction zone (Tauern Window, Eastern Alps). Tectonics 39:e2019TC005942

Handy MR, Schmid SM, Bousquet R, Kissling E, Bernoulli D (2010) Reconciling plate-tectonic reconstructions of Alpine Tethys with the geological-geophysical record of spreading and subduction in the Alps. Earth Sci Rev 102:121-158

Höck V, Koller F (1989) Magmatic evolution of the Mesozoic ophiolites in Austria. Chem Geol 77:209-227

Höck V, Miller C (1987) Mesozoic ophiolitic sequences and nonophiolotic metabasites in the Hohe Tauern. In: Flügel HW, Faupl P (eds) Geodynamics of the Eastern Alps. Deuticke, Vienna, pp 16-33

Höck V, Scharbert S (1989) Metabasalts from the Central Part of the Hohe Tauern (Austria): Genetic implications from $\mathrm{Sr}$-isotope and trace element studies. Mitt Österr Geol Ges 81:151-165

Holland T, Norris R (1979) Deformed pillow lavas from the central Hohe Tauern, Austria, and their bearing on the origin of epidote-banded greenstones. Earth Planet Sci Lett 43:397-405

Kaczmarek M-A, Müntener O, Rubatto D (2008) Trace element chemistry and $\mathrm{U}-\mathrm{Pb}$ dating of zircons from oceanic gabbros and their relationship with whole rock composition (Lanzo, Italian Alps). Contrib Miner Petrol 155:295-312

Kurz W (2006) Penninic paleogeography from the Western toward the Eastern Alps-still open questions? Int Geol Rev 48:996-1022

Kurz W, Neubauer F, Genser J, Dachs E (1998) Alpine geodynamic evolution of passive and active continental margin sequences in the Tauern Window (eastern Alps, Austria, Italy): a review. Geol Rundsch 87:225-242

Li X-H, Faure M, Lin W, Manatschal G (2013) New isotopic constraints on age and magma genesis of an embryonic oceanic crust: the Chenaillet Ophiolite in the Western Alps. Lithos 160:283-291

Li X-H, Faure M, Rossi P, Lin W, Lahondère D (2015) Age of Alpine Corsica ophiolites revisited: Insights from in situ zircon $\mathrm{U}-\mathrm{Pb}$ age and O-Hf isotopes. Lithos 220:179-190

Liati A, Froitzheim N (2006) Assessing the Valais ocean, Western Alps: U-Pb SHRIMP zircon geochronology of eclogite in the Balma unit, on top of the Monte Rosa nappe. Eur J Mineral 18:299-308

Liati A, Gebauer D, Fanning CM (2003) The youngest basic oceanic magmatism in the Alps (Late Cretaceous; Chiavenna unit, Central Alps): geochronological constraints and geodynamic significance. Contrib Miner Petrol 146:144-158
Liati A, Froitzheim N, Fanning CM (2005) Jurassic ophiolites within the Valais domain of the Western and Central Alps: geochronological evidence for re-rifting of oceanic crust. Contrib Miner Petrol 149:446-461

Lombardo B, Rubatto D, Castelli D (2002) Ion microprobe U-Pb dating of zircon from a Monviso metaplagiogranite: implications for the evolution of the Piedmont-Liguria Tethys in the Western Alps. Ofioliti 27:109-117

Ludwig K (2012) Isoplot/Ex, v. 3.75. Berkeley Geochronology Center Special Publication, p 5

Manatschal G, Müntener O (2009) A type sequence across an ancient magma-poor ocean-continent transition: the example of the western Alpine Tethys ophiolites. Tectonophysics 473:4-19

McDonough WF, Sun S-S (1995) The composition of the Earth. Chem Geol 120:223-253

Meisel T, Melcher F, Tomascak P, Dingeldey C, Koller F (1997) $\mathrm{ReOs}$ isotopes in orogenic peridotite massifs in the Eastern Alps, Austria. Chem Geol 143:217-229

Melcher F, Meisel T, Puhl J, Koller F (2002) Petrogenesis and geotectonic setting of ultramafic rocks in the Eastern Alps: constraints from geochemistry. Lithos 65:69-112

Miller C (1977) Chemismus und phasenpetrologische Untersuchungen der Gesteine aus der Eklogitzone des Tauernfensters, Österreich. Tschermaks Mineralogische Und Petrographische Mitteilungen 24:221-277

Miller C, Konzett J, Tiepolo M, Armstrong R, Thöni M (2007) Jadeite-gneiss from the Eclogite Zone, Tauern Window, Eastern Alps, Austria: metamorphic, geochemical and zircon record of a sedimentary protolith. Lithos 93:68-88

Nagel T, Herwartz D, Rexroth S, Münker C, Froitzheim N, Kurz W (2013) Lu-Hf dating, petrography, and tectonic implications of the youngest Alpine eclogites (Tauern Window, Austria). Lithos 170:179-190

Nasdala L et al (2008) Zircon M257-a homogeneous natural reference material for the ion microprobe $\mathrm{U}-\mathrm{Pb}$ analysis of zircon. Geostand Geoanal Res 32:247-265

Neubauer F, Liu X, Cao S, Dong Y, Merschdorf I (2019) Opening and closure of the Penninic ocean basin at the Alpine-Carpathian transition: new structural data and $\mathrm{U}-\mathrm{Pb}$ zircon ages. In: Geophysical research abstracts, vol 21. p 1

Pearce JA (2008) Geochemical fingerprinting of oceanic basalts with applications to ophiolite classification and the search for Archean oceanic crust. Lithos 100:14-48

Principi G et al (2004) The pre-orogenic volcano-sedimentary covers of the western Tethys oceanic basin: a review. Ofioliti 29:177-211

Raith M, Mehrens C, Thöle W (1980) Gliederung, tektonischer Bau und metamorphe Entwicklung der penninischen Serien im südlichen Venediger-Gebiet, Osttirol. Jahrbuch Der Geol Bundesanstalt 123:1-37

Rampone E, Hofmann AW, Raczek I (1998) Isotopic contrasts within the Internal Liguride ophiolite (N. Italy): the lack of a genetic mantle-crust link. Earth Planet Sci Lett 163:175-189

Rampone E, Hofmann AW, Raczek I (2009) Isotopic equilibrium between mantle peridotite and melt: evidence from the Corsica ophiolite. Earth Planet Sci Lett 288:601-610

Rubatto D, Hermann J (2003) Zircon formation during fluid circulation in eclogites (Monviso, Western Alps): implications for $\mathrm{Zr}$ and $\mathrm{Hf}$ budget in subduction zones. Geochim Cosmochim Acta 67:2173-2187

Rubatto D, Scambelluri M (2003) U-Pb dating of magmatic zircon and metamorphic baddeleyite in the Ligurian eclogites (Voltri Massif, Western Alps). Contrib Miner Petrol 146:341-355

Rubatto D, Gebauer D, Fanning M (1998) Jurassic formation and Eocene subduction of the Zermatt-Saas-Fee ophiolites: 
implications for the geodynamic evolution of the Central and Western Alps. Contrib Miner Petrol 132:269-287

Schaltegger U, Desmurs L, Manatschal G, Müntener O, Meier M, Frank M, Bernoulli D (2002) The transition from rifting to seafloor spreading within a magma-poor rifted margin: field and isotopic constraints. Terra Nova 14:156-162

Schmid SM, Fügenschuh B, Kissling E, Schuster R (2004) Tectonic map and overall architecture of the Alpine orogen. Eclogae Geol Helv 97:93-117

Schmid SM, Scharf A, Handy MR, Rosenberg CL (2013) The Tauern Window (Eastern Alps, Austria): a new tectonic map, with crosssections and a tectonometamorphic synthesis. Swiss J Geosci 106:1-32

Schneider KP, Hoffmann JE, Münker C, Patyniak M, Sprung P, Roerdink D, Garbe-Schönberg D, Kröner A (2019) Petrogenetic evolution of metabasalts and metakomatiites of the lower Onverwacht Group, Barberton Greenstone Belt (South Africa). Chem Geol 511:152-177

Spear FS, Franz G (1986) P-T-evolution of metasediments from the Eclogite Zone, south-central Tauern Window, Austria. Lithos 19:219-234
Stacey J, Kramers J (1975) Approximation of terrestrial lead isotope evolution by a two-stage model. Earth Planet Sci Lett 26:207-221

Stampfli G, Mosar J, Marquer D, Marchant R, Baudin T, Borel G (1998) Subduction and obduction processes in the Swiss Alps. Tectonophysics 296:159-204

Stucki A, Rubatto D, Trommsdorff V (2003) Mesozoic ophiolite relics in the Southern Steep Belt of the Central Alps. Swiss Bull Mineral Petrol 83:285-299

Sun S-S, McDonough WF (1989) Chemical and isotopic systematics of oceanic basalts: implications for mantle composition and processes. Geol Soc Lond Spec Publ 42:313-345

Tribuzio R, Thirlwall MF, Vannucci R (2004) Origin of the gabbroperidotite association from the Northern Apennine Ophiolites (Italy). J Petrol 45:1109-1124

von Quadt A, Günther D, Frischknecht R, Zimmermann R, Franz G (1997) The evolution of pre-Variscan eclogites of the Tauern Window (Eastern Alps): a Sm/Nd-, conventional and Laser ICP-MS zircon U-Pb study. Schweiz Mineral Petrogr Mitt 77:265-279 